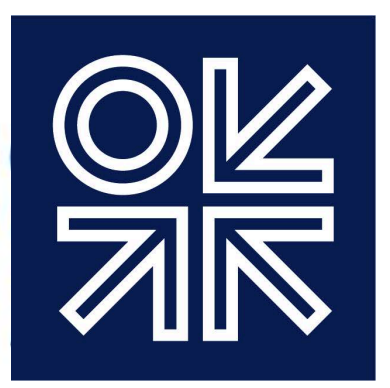

THE OXFORD

INSTITUTE

FOR ENERGY

STUDIES

December 2019

\title{
Canadian LNG Competitiveness
}

Beyond LNG Canada, will the country overcome self-inflicted regulatory uncertainty and high projected capital costs to become a global player?

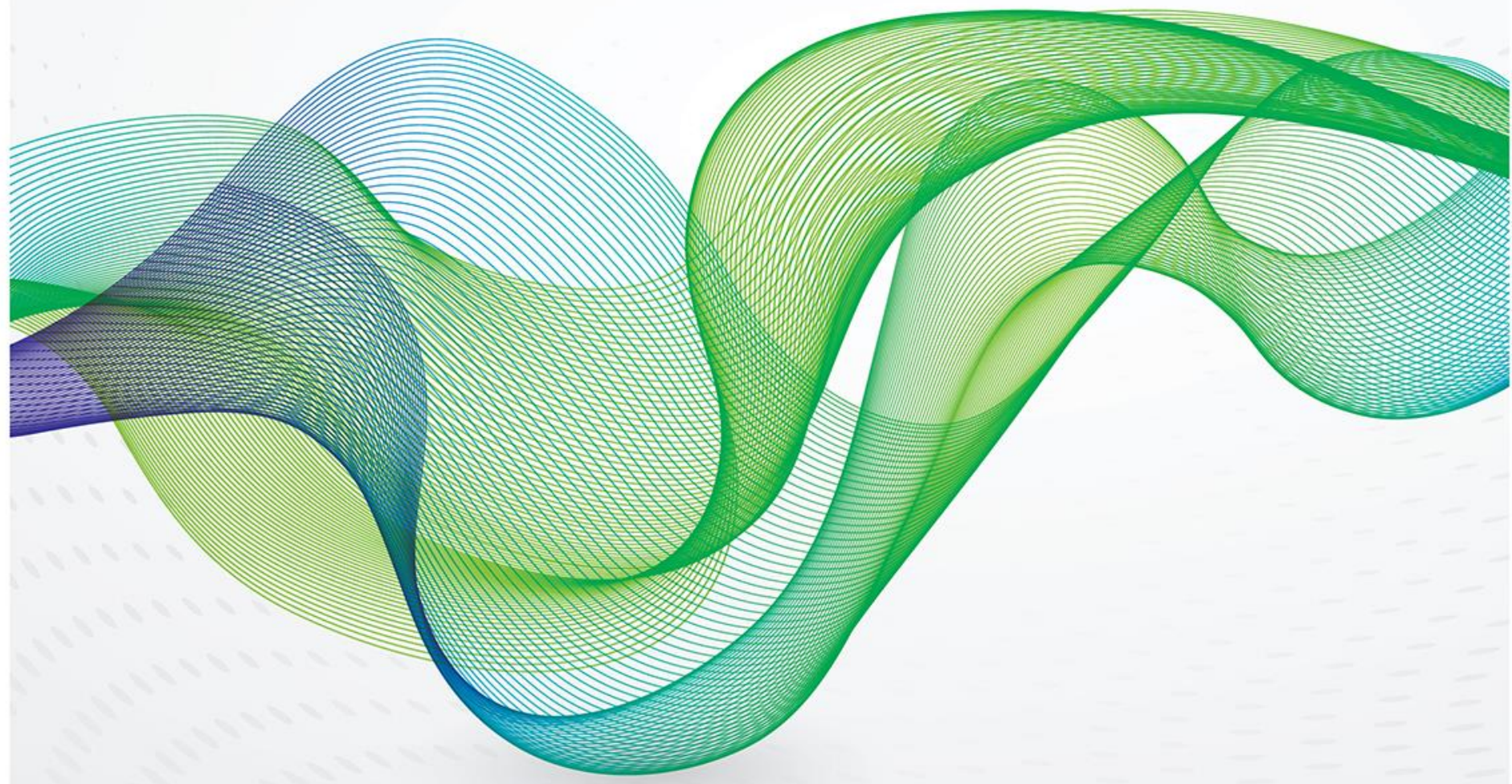


The contents of this paper are the author's sole responsibility. They do not necessarily represent the views of the Oxford Institute for Energy Studies or any of its members.

Copyright () 2019

Oxford Institute for Energy Studies

(Registered Charity, No. 286084)

This publication may be reproduced in part for educational or non-profit purposes without special permission from the copyright holder, provided acknowledgment of the source is made. No use of this publication may be made for resale or for any other commercial purpose whatsoever without prior permission in writing from the Oxford Institute for Energy Studies.

ISBN 978-1-78467-153-2

DOI: https://doi.org/10.26889/9781784671532 


\section{Preface}

In our analysis of the global LNG market it has been clear for some time that Canada has huge gas resources potentially available for export, especially since sales into the US have been curtailed by the rise of shale gas production south of the border. The key question has always been whether their development could be done in a cost-effective manner to allow Canadian LNG to compete with emerging supplies from the rest of the world. The recent decision by Shell and its partners to take a final investment decision on the LNG Canada project has underlined that they, at least, believe that the prospects are good in British Columbia, based on low upstream costs and the resolution of numerous midstream and regulatory issues.

Peter Findlay now provides a detailed analysis of his view on the competitive position of Canadian LNG as he assesses the economics of the current project and also the prospects for future development. At OIES we have always believed that it is very important to get a view on topics such as this from inside the country itself, and as Peter is based in Calgary where he works for the Criterium Group he is ideally placed to provide some domestic insight. We thank him for his important contribution to the debate on the competitive position of various sources of LNG supply by providing some context from a large North American gas producer, and we hope that the paper will be of broad interest to a range of actors in the global gas market.

James Henderson

Director, Natural Gas Programme

Oxford Institute for Energy Studies 


\section{Acknowledgements}

I would like to thank James Henderson and Bassam Fattouh of the institute for supporting this research.

I am grateful to Robert Skinner for his help in guiding and editing the paper. Greg Stringham of GS3 Strategies consulting firm, greatly helped inform the required action list, from a government perspective. Andy Doyle-Linden provided very helpful insights and suggestions during the review process. Zsolt Vigh helpfully provided insights on methane reduction sources and comparative LNG liquefaction emissions across the world.

Thank you to our Criterium Group team in Calgary and London for its support of this work and the ongoing research in general into North American midstream markets and LNG.

I would also like to thank the numerous senior executives from various NOCs, supermajors, upstream producers, midstream operators, petrochemical manufacturers, investment funds, and advisory firms who provided insights and perspectives for this paper.

Most importantly, I owe much gratitude to my wife and family for their patience and support while I worked through the research.

Peter Findlay

Calgary, December 2019 


\section{Glossary / Acronyms}

AECO

$\mathrm{BC}$

bcfd

Brownfield

CERI

COD

EPC

ESG

FEED

FERC

FID

FLNG

GDP

GHG

Greenfield

IEA

IRR

kWh

LNG

mcf

mmbtu

mtpa

NDP

NEB

NGL

NOC

$\mathrm{PDH}$

PST

ROW

tcf

UNDRIP

USGC

WCSB
Alberta Energy Company; Canadian benchmark price for natural gas

British Columbia (the Canadian province of)

billion cubic feet per day

A new project instalment that is an expansion or overhaul of a past installation

Canadian Energy Research Institute

Commercial Operation Date; the day the project becomes fully operational

Engineering, Procurement, and Construction contractor

Environmental, Social, and Governance

Front End Engineering Design

Federal Energy Regulatory Commission (US regulatory body)

Final Investment Decision

Floating Liquefied Natural Gas

Gross Domestic Product

Greenhouse Gas

A project instalment built in a new area, not expanding a past installation International Energy Agency

Internal Rate of Return

kilowatt hour

Liquefied Natural Gas

million cubic feet

million British thermal units

million tonnes per year

New Democratic Party: A political party that exists at both provincial and federal levels in Canada and is traditionally the most left-wing of the major parties.

National Energy Board (of Canada)

Natural Gas Liquid

National Oil Company

Propane Dehydrogenation

Provincial Sales Tax

Right of way

trillion cubic feet

United Nations Declaration of Rights of Indigenous Peoples

United States Gulf of Mexico Coast

Western Canadian Sedimentary Basin 


\section{Contents}

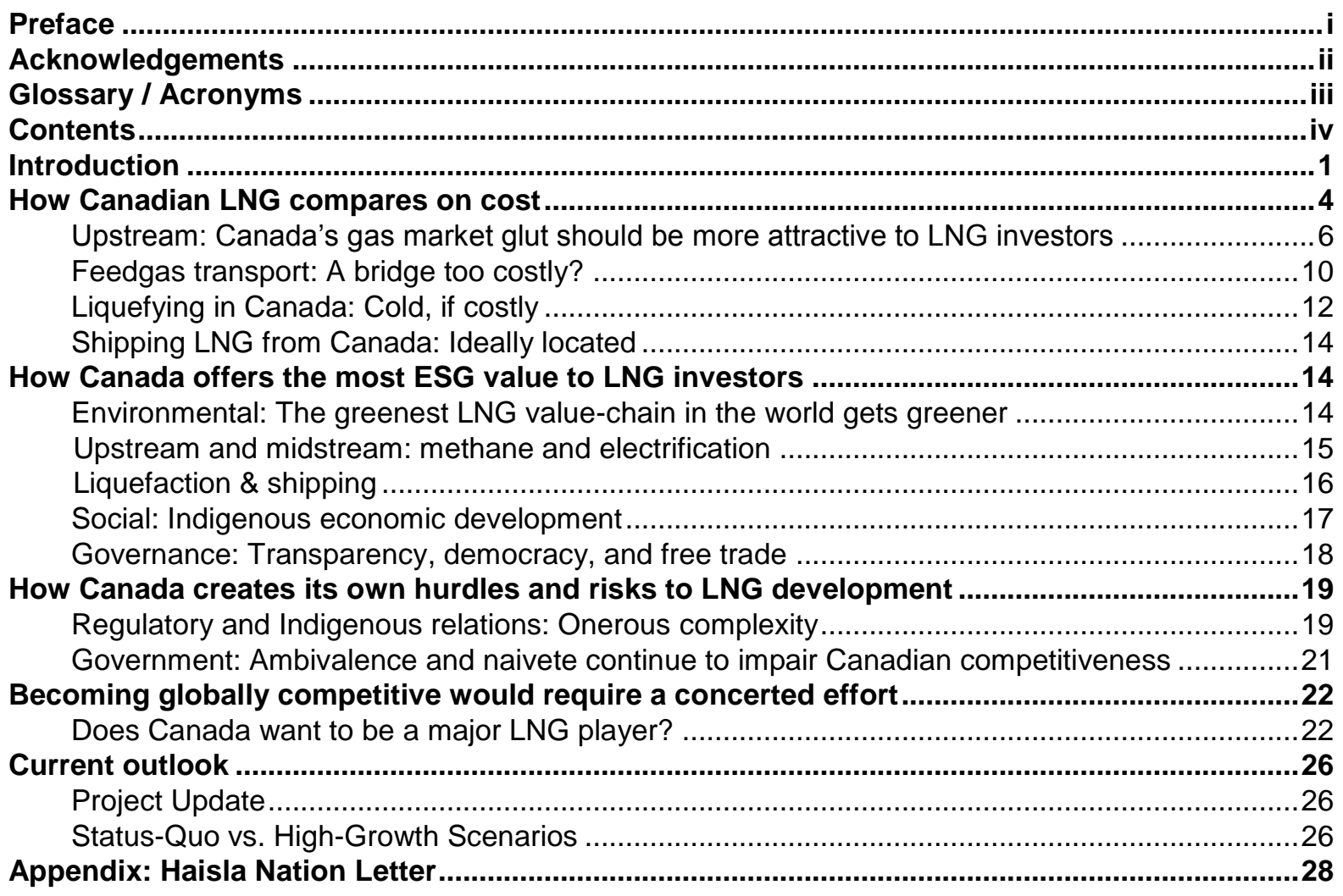

\section{Figures \& Tables}

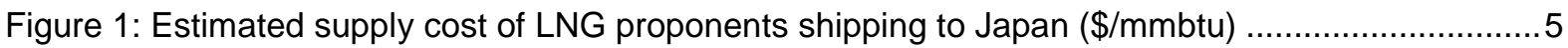

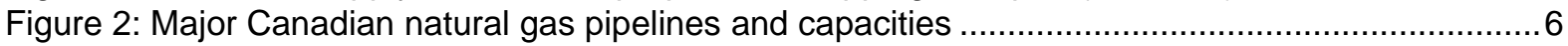

Figure 3: Impact of shale gas production on North American Gas supply and demand ..................... 7

Figure 4: Price history and outlook for AECO and Station 2 vs. Henry Hub................................... 8

Figure 5: Production vs. revenue split for Seven Generations Energy (Q2 2019) .............................

Figure 6: Selected proposed feedgas pipelines for Western Canadian LNG ..................................11

Figure 7: Capital cost comparison for liquefaction (USGC vs. Canada) ....................................13

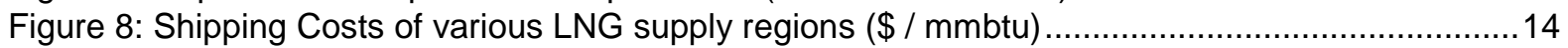

Figure 9: BC LNG GHG for liquefaction versus other LNG supply regions ...................................16

Figure 10: Full-value chain analysis of GHG Emissions from BC LNG, consumed in China .............17

Figure 11: Net GHG Emissions Impact of LNG Canada alone (including expansion) vs. Coal ...........23

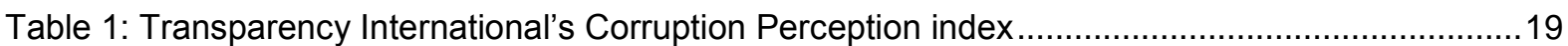




\section{Introduction}

At the moment, most global natural gas demand outlooks are bullish for the coming few decades. The IEA; supermajors Exxon, BP, and Shell; and research firms like Wood Mackenzie and IHS Markit predict global gas demand to increase by roughly a third by $2035 .{ }^{1}$ The bullish outlooks also predict a near doubling of LNG consumption - a projected growth rate higher than all combined renewables. ${ }^{2}$ (The Oxford Institute for Energy Studies [OIES] view has been somewhat more cautious, though it still foresees substantial growth.) A growing LNG market is dependent upon coal-to-gas switching, which is projected to play a critical role in helping reduce global greenhouse gas (GHG) emissions, and reducing premature deaths from harmful air pollution, especially in developing economies. ${ }^{3}$ As well, some analysts project a shift of some of global LNG trade towards commodification and spot markets as shortterm liquidity grows. ${ }^{4}$ Global competition to supply the projected LNG demand growth is fierce - this paper examines how Canada stacks up against other exporting countries.

The world's fourth largest producer and fifth largest exporter of natural gas today, Canada was for decades a vital supplier to the United States, exporting as much as 9.1 bcfd, as the world's second largest gas exporter until 2006. ${ }^{5}$ The shale gas revolution then upended North American markets. Lowcost shale gas production has accelerated from 2007 to propel the US ahead of Russia as the leading global producer, not to mention a net exporter since 2017 . This prodigious $60 \%$ growth in US production (roughly $30 \mathrm{bcfd}$ ) has increasingly obviated American demand for Canadian natural gas - production north of the border has effectively flatlined.

Often overlooked in this story, is that the production technology that underpinned the US shale revolution quickly unlocked vast new gas reserves in Canada. The country's Montney, Spirit River, and Duvernay plays in the Western Canadian Sedimentary Basin (WCSB) alone have since been estimated to contain more than 650 tcf of "marketable" gas reserves. Compare this with estimates of US Permian basin gas reserves of between 125-280 tcf which bring total US proved reserves to between 700 and 800 tcf, across all basins. $6,7,8,9$ (Note that the US is emptying these basins more rapidly, producing 80.5 bcfd in 2018, versus 17.9 bcfd in Canada.)

This boon in WCSB gas reserves was covered in the 2015 OIES report on options for Canadian gas. ${ }^{10}$ It also provided a summary of the roughly 20 Canadian LNG project proposals then active - investors were attracted to the vast reserves and the variety of LNG business model options available in Canada (many Asian investors were and still are interesting in controlling the entire LNG value-chain starting from upstream production). Since that time, investor interest in Canadian projects has waned and only the $13 \mathrm{mtpa}$ LNG Canada plant has been sanctioned; the plant includes a yet unsanctioned $13 \mathrm{mtpa}$ expansion option. ${ }^{11}$ While Canadian LNG sputtered, despite starting from behind with a higher cost of feedgas, and much greater shipping distances to Asia, the US Gulf Coast (USGC) has attracted a deluge of LNG investment: $117 \mathrm{mtpa}$ has been built or is sanctioned. ${ }^{12}$

The outlook has been bleak for Canadian natural gas producers since 2015 - Alberta's gas price index AECO has traded at a paltry $35-40 \%$ of the already world-competitive Henry Hub price in recent years

\footnotetext{
Wood Mackenzie, Shell, BP, others (2019 outlook until 2035)

2 Ibid.

${ }^{3}$ International Energy Agency, The Role of Gas In Today's Energy Transitions, 2019

${ }^{4}$ The OIES recent forum on LNG summarizes critical global trends: Oxford Institute for Energy Studies, "LNG In Transition: From Uncertainty To Uncertainty", Oxford Energy Forum, no. 119 (2019).

${ }^{5}$ BP, Statistical Review of World Energy, All Data 1965-2018, 2019.

${ }^{6}$ See the United States Geological Survey (USGS) and the EIA for US estimates. Note that marketable and proved are both used as estimates to consider what is economically feasible given current economics, and these estimates change over time based on then current production economics.

${ }^{7}$ NEB, BC Oil \& Gas Commission, AER, Ministry of Natural Gas Development (BC). The Ultimate Potential For Unconventional Petroleum From The Montney Formation Of British Columbia And Alberta, 2013.

${ }^{8}$ NEB, Alberta Geological Survey. Duvernay Resource Assessment Energy Briefing Note, 2017.

9 "The Competitiveness of Canadian Natural Gas and LNG on a Global Scale" https://sproule.com/

${ }^{10}$ leda Gomes, Natural Gas In Canada: What Are The Options Going Forward? (Oxford: Oxford Institute for Energy Studies, 2019).

${ }^{11}$ LNG Canada partners include Shell (40\%), PETRONAS (25\%), PetroChina (15\%), Mitsubishi (15\%), and Korea Gas (5\%)

12 U.S. Energy Information Administration (EIA)
} 
- sometimes even negative. Such depressed pricing is remarkable for an index that represents roughly $14 \mathrm{bcfd}$, or $4 \%$ of global production. Because demand growth for natural gas in Western Canada is limited while condensate demand continues to rise due to oil sands plays that do not decline like other global oil basins, this paper submits that Western Canada is likely to offer one of the lowest-priced sources of global gas for decades to come. ${ }^{13}$ So how is a region with such low gas prices from a practically inexhaustible resource base, shipping times to Asia less than half those from the USGC, a trade-friendly democratic government, and leading environmental performance, struggling to compete as the next wave of global LNG plants are sanctioned?

Building an LNG value chain across British Columbia (BC), Canada's westernmost province, has inherent challenges. Due to geographic isolation, developers assume that capital costs for liquefaction terminal construction greatly exceed those in brownfield clusters like the USGC. There is a mountainous swath of hinterland to cover by pipeline before the gas is liquefied at the coast. The Canadian labour market for skilled trades is historically less robust and more prone to union demands than in the US. (This is more of a problem in BC where much of LNG capital will be spent than in Alberta, where labour markets are less unionized). That said, developers were certainly cognizant of these headwinds when they enthusiastically proposed Canadian projects earlier this decade. Labour headwinds are becoming less formidable: opportunities increasingly exist to construct more of the liquefaction terminal overseas. Also labour rates are more competitive due to high unemployment - it is estimated that $60,000-100,000$ skilled jobs have been lost in Canada's Energy Sector since 2014 - and a 33\% increase in the USD/CAD exchange rate since $2014 .{ }^{14}$

Beyond capital costs, it may strike non-Canadians as strange that Canada itself is frustrating, if not undermining, its own LNG prospects. Changes in government to regimes less supportive of, or appearing ambivalent about, resource development, are in part reflected in significant changes to provincial and federal regulations regarding resource rent, environmental assessments, climate change policies, and regulatory oversight, compounded by a series of court decisions and appeals by environmental organizations and Indigenous peoples (First Nations) against projects. These and more have created a general atmosphere of uncertainty and perceived risk to capital investments in fossil fuel developments in general. The result is Canada losing out on the order of trillions of dollars in overall macroeconomic impact over the next 40 years, not to mention the opportunity to make a significant reduction in global emissions by displacing the coal burned for electric power in Asia. ${ }^{15}$ The forgone macroeconomic benefit is simply redirected to more predictable supply jurisdictions, primarily the US Gulf Coast, Russia, Qatar, and East Africa. Likewise, this paper argues that Canadian LNG is GHG positive; the less Canadian LNG, the higher the GHG emissions along the LNG value-chains that terminate in Asia. This is due to the combination of Canada's favourable proximity, pre-liquefaction temperature, proactive methane release management and the use of hydroelectric power for both upstream and liquefaction.

It must seem odd that a country whose economy is so intertwined with, and dependent upon, the safe and environmentally responsible extraction, transportation, and processing of natural resources, takes such an incoherent and ineffectual approach to regulating it. ${ }^{16}$ This problem has dogged Canada's oil sands and beggared smaller independent oil and gas producers, creating the well-publicized battles to get export pipelines built. Proponents of petrochemical projects have had to grapple with uncertainty around ambiguous and non-committal government incentives. Producers and midstream operators often wait substantially longer for an approval of a project than it takes to build the project. Regulations and entire regulatory bodies change abruptly and unpredictably with the winds of political change. Governments often choose rent-seeking over incentivization or even simple clarity, assuming

\footnotetext{
${ }^{3}$ Russia and Qatar may be able to show lower feedgas costs for LNG, though the extent of subsidization is unclear. Canada is predicted to have structural cost advantages for gas feedstock versus most of the US and Australia.

${ }^{14}$ Low end of range: Statistics Canada. Analysis: Viewpoint Group Research; High end of range: CAPP / CSUR

${ }^{15}$ LNG Canada is the largest single private investment in Canadian history and is expected to generate of the order of $\$ 320$ 560 billion in macroeconomic impact over a period of 40 years (see final section of this paper for details). Multiple world-scale projects would easily exceed \$1 trillion, and this does not include related value-chains such as petrochemicals and oil.

${ }^{16}$ The combined upstream, midstream, downstream and hydrocarbon-related power industries (not including manufacturing activities that underpin these sectors) constitute roughly $\$ 150$ billion of Canadian GDP, making energy arguably the largest sub-sector of the Canadian economy, depending on categorization, and by far Canada's largest export (Statistics Canada).
} 
investment will flow to Canada regardless of the fiscal regime imposed. Then, when investment retreats, governments change, reviews are launched, all the while instilling uncertainty and therefore risk.

Doug Suttles, CEO of EnCana, which until recently was Canada's largest natural gas producer and in the past revered as a homegrown Canadian "national champion", highlighted the feeling among executives and investors earlier this year:

...complexity and uncertainty in the regulatory process is orders of magnitude higher [in Canada, where Encana now produces roughly just one-third of its oil and gas, compared with the U.S.] ...The Montney now is the biggest area of growth in Canada - it's where we're focusing our attention - and if it sat in the United States, it would probably be producing two, three, four times what it is producing today. ${ }^{17}$

In October 2019, Encana, announced it was moving its headquarters to the United States and accordingly changed its name to Ovintiv, to remove any reference to Canada. ${ }^{18}$ (Similarly, Canada's iconic TransCanada Corporation renamed itself TC Energy earlier in 2019, though it maintains its headquarters in Calgary.)

The issue is not necessarily due to political inclination - ironically, it was a right-leaning BC Liberal government that introduced the targeted BC LNG tax, and a succeeding left-leaning NDP government that repealed it - in response to $\mathrm{BC}$ unions seeking employment. Industry advocates carp that the current situation in Canadian energy is redolent of the collateral damage of historic energy policy in Canada (or lack thereof) - particularly in the 1970s and 1980s with the government intervention of oil price controls and the "National Energy Program". The program was imposed by the government of Prime Minister Pierre Trudeau (father of current Prime Minister Justin Trudeau) and was built on "three basic principles": ${ }^{19}$

- security of supply and the ultimate independence from the world oil market [following concern around the oil price shocks of the 1970s];

- opportunity for all Canadians to participate in the energy industry; particularly oil and gas, and to share in the benefits of its expansion ["Canadianizing" the industry]; and

- fairness, with a pricing and revenue-sharing regime which recognizes the needs and rights of all Canadians. [This was to pay for the multitude of programs to achieve the first two objectives, all predicated on an ever-rising world oil price.]

Shortly after the NEP's launch, the world oil price levelled off, then fell. Notwithstanding attempts to offset the price effects, investment declined. Worst of all for all Canadians, the NEP poisoned global investor sentiment for the Western Canadian Sedimentary Basin (WCSB) for years, if not decades.

In June 2019, the federal government under Justin Trudeau passed Bill C-69 (referred to by the industry as the "Anti-pipeline Bill") which revamps how major energy and natural resource projects are assessed and approved. This led to remonstrances from Canada's oil and gas industry and the vociferous opposition of most provincial governments across the country. ${ }^{20}$ Soon after being elected, Prime Minister Trudeau voiced his government's philosophy regarding approval processes for developments, stating "governments grant permits; communities grant permission". ${ }^{21}$ This signalled his government's support for the ambiguous and almost anarchic notion of "social license" - effectively abdicating regulatory responsibility to national and international environmental organizations, as well as indigenous and concerned citizens, to frustrate if not totally shut down the Canadian hydrocarbons industry. ${ }^{22}$ The bill grants significantly more oversight and power to the Cabinet and the general public and anyone else for that matter (having reversed the previous legislation that restricted appearance before tribunals to those who could demonstrate that they would be directly affected by a development) rather than the politically independent regulatory boards staffed with appointed economic, engineering,

${ }_{17}$ Dan Healing, "Encana CEO Says Canadian Oiffield Would Produce More If Regulated In U.S.", CBC News, 2019, https://www.cbc.ca/news/canada/calgary/encana-canadian-oilfield-regulation-1.5145611

${ }^{18}$ Orland, Kevin. "'Canada' Is Becoming A Dirty Word In The Oil Patch". Bloomberg News, 2019.

${ }^{19}$ MacEachen, Allan. The Budget. Ottawa: Minister of Finance / Deputy Prime Minister, Department of Finance Canada, 1980.

${ }^{20}$ Certain elements of the bill were welcomed by industry and the bill, as a whole, was supported by the mining industry.

${ }^{21}$ https://www.cbc.ca/player/play/2684686536

${ }^{22}$ For an academic review of the meaning of "social license", see Colton, John, Stewart Fast, Monica Gattinger, Joel Gehman, and Jennifer Winter. "Energy Projects, Social Licence, Public Acceptance And Regulatory Systems In Canada: A White Paper". SSRN Electronic Journal, 2016. doi:10.2139/ssrn.2788022. 
environmental and sociological experts. Despite the promise that C-69 would streamline the regulatory process, it contains provisions for more complex requirements regarding climate change, social, and gender impacts of project development amid vague clauses that could be exploited through drawn-out court challenges. It is these court challenges that have caused uncertainty for investors. Sceptics and cynics argue that the irony behind this "social license" demanded by project detractors, is that the concept was created never to be granted - an illusion, or Fata Morgana. ${ }^{23}$ More objectively, policy experts argue in probably the most thorough academic review of "social license" that: ${ }^{24}$

Social licence entails an additional layer of 'regulation', albeit an amorphous one. A central lesson of the 20th century experience is that regulation comes at a cost, and that excessive regulation and intervention can lead to paralysis and 'government failure'... The institutionalization of social licence also has identifiable risks. It is likely to increase incentives for "rent-seeking behaviour." The threat of veto, or even obstruction, endows the affected group with leverage that can result in extraction of rents that are disproportionate to impacts.

Bill C-69 optimists, though a minority among academic law faculty, developers and investors, admit that even if the bill brings unwanted delays and uncertainty, developers that truly demonstrate project designs with the highest levels of environmental performance and proactively consult Indigenous peoples to ensure shared benefits should be able to clear any regulatory hurdles and use the process as a "certification" of environmental, social, and governance (ESG) leadership. ${ }^{25}$

The upshot of Bill C-69 for Canadian LNG Competitiveness is that rather than adding clarity to the regulatory process, uncertainty and subjectivity looks to have increased, at least in the minds of all energy executives that were interviewed for this paper. This is difficult for investors to swallow and unintentionally inflicts sizeable harm to the growth prospects of the Canadian economy, the world's tenth largest. Meanwhile, of projects soon subject to the new legislation, there is one LNG export terminal (Cedar LNG) and one major pipeline that feeds a proposed LNG terminal (Energy Saguenay) that will be a test of Bill C-69's impact on development in general. ${ }^{26}$

\section{How Canadian LNG compares on cost}

LNG investors are primarily attracted to cost competitiveness and an alignment of LNG business model to overarching strategy; security of supply is decreasingly relevant due to the raft of low-cost and abundant sources of emerging global natural gas supply. Reports and analyses covering the global LNG competitive landscape tend to include one or more stacked bar charts comparing delivered breakeven supply costs - and this paper is no different. Figure 1 demonstrates that for shipping to Asia (which drives the bulk of current and new demand), Canadian LNG is relatively competitive with USGC greenfield LNG and other global projects, especially when using wet gas production. (For LNG Canada's Phase 1, this paper views Shell's break-even cost estimates to be more accurate at $\$ 7.2 / \mathrm{mmbtu}$ than WoodMac's at $\$ 8.2$ - the consortium of partners would have been unlikely to reach the 2018 FID with such costs.). ${ }^{27}$ All North American projects (beyond the LNG Canada expansion, which benefits from the higher cost LNG Canada first phase) struggle to compete against the clear cost advantages of brownfield additions in gas-prolific Qatar, though they compete well with other global proponents.

Canada is seen as less cost-competitive when shipping to Europe, due primarily to the high cost of transporting gas across the continent to Canada's East Coast (perhaps $\$ 2-3 / \mathrm{mmbtu}$ ). This burden outweighs Canada's close shipping distance to European markets (compared with the USGC), though

\footnotetext{
${ }^{23}$ Epithet employed by National Post polemicist Rex Murphy.

24 Ibid. 22

${ }^{25}$ See University of Calgary Law Professor Martin Olszynski's articles relating to Bill C-69 at https://ablawg.ca for arguments defending Bill C-69

${ }^{26}$ Snyder, Jesse. "Two Proposed LNG Projects Will Serve As A Testing Ground For Trudeau's Controversial Bill C-69". National Post, 2019.

${ }^{27}$ Wood Mackenzie, The Economics Of Canadian LNG: Can We Do Better?, 2019, https://www.woodmac.com/reports/gasmarkets-the-economics-of-canadian-Ing-can-we-do-better-312208. Used with permission. Cost estimates assume 15\% return for the upstream portion of integrated projects, and $10 \%$ for liquefaction. For integrated projects, the required return is estimated at $12 \%$.
} 
there is hope among several smaller proponents that they could source gas in closer proximity to liquefaction on the East Coast.

Figure 1: Estimated supply cost of LNG proponents shipping to Japan (\$/mmbtu)

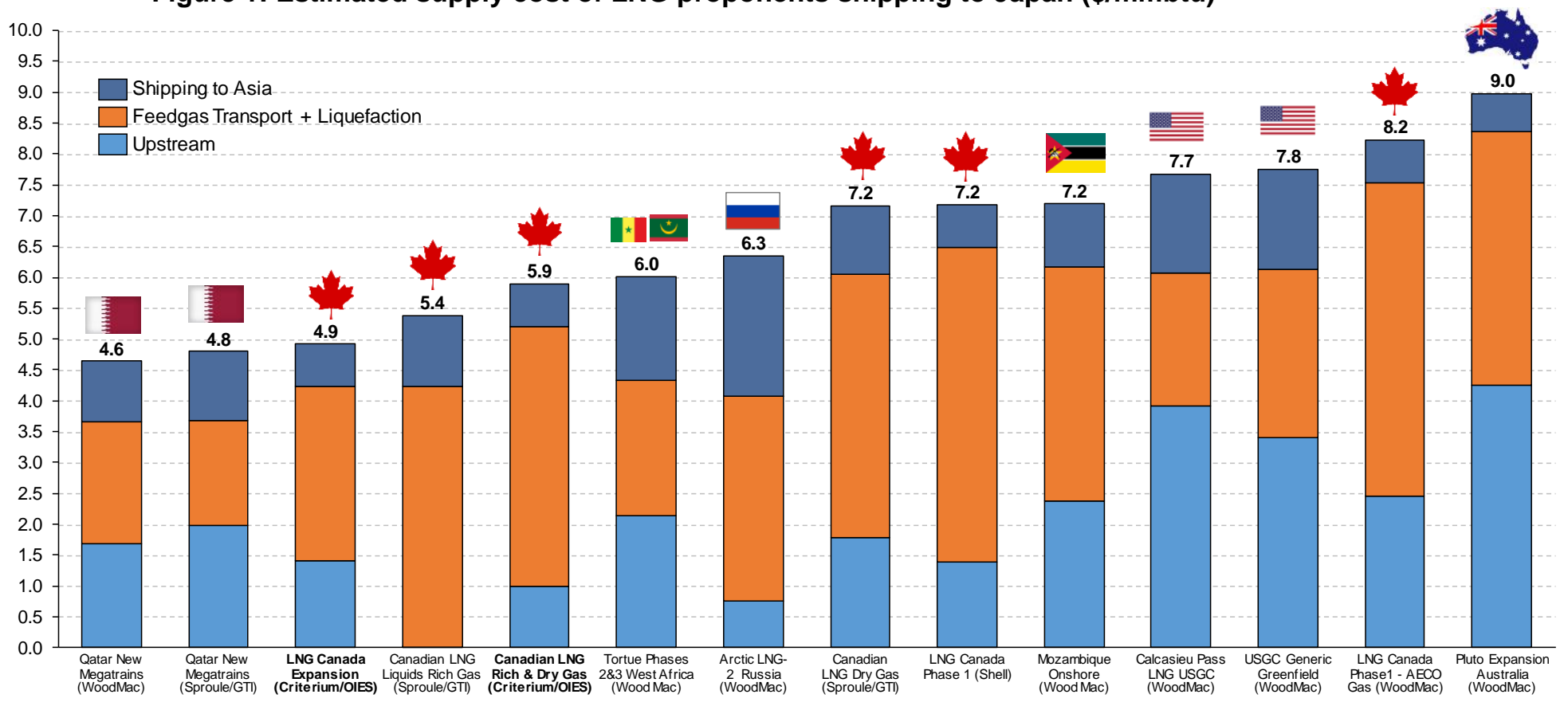

Sources: (with permission): Criterium Group / OIES, Sproule / GTI, ${ }^{28}$ Shell, WoodMac ${ }^{29}$

These periodically produced supply cost estimates do give a directional understanding of competitiveness, but readers should refrain from drawing definitive conclusions. Many such supply cost estimates are presented in LNG prospectuses, though caveat emptor requires investors to dig further into the nuance and complexity that cannot be deduced from these charts, including, but not limited to:

- Uncertainty: Some drivers are highly uncertain, like upstream costs. For example, Wood Mackenzie estimates LNG Canada's upstream costs around $\$ 2.4 / \mathrm{mmbtu}$, Shell estimates their cost as significantly cheaper at $\$ 1.4$, while the market price at Station 2 in the Montney has averaged $\$ 0.8$ over the past year. Much of the producing region is projected to be able to sustain much lower cost, and some proponents even tout potential negative pricing (such differentials typically get arbitraged away over time, however; see section on upstream below). Capital cost uncertainty varies greatly depending on the contractual relationship with the engineering, procurement and construction (EPC) contractor(s) as well as how "greenfield" the project is. Tax rates and government incentives are subject to the winds of political change. Shipping costs, for which Canadian proponents are highly competitive, are the easiest to predict and the most difficult to reduce.

- Past and Future Projects: Fully greenfield proposals carry heavy price burdens which may appear to disqualify the proponent. What supply cost stack charts do not typically show, is how a greenfield investment enables highly competitive brownfield additions. For example, LNG Canada's expansion would double the size of the operation to 26 mtpa with major savings in capital costs and feedgas transport, making the expansion on its own one of the more attractive incremental LNG volume additions in the world (only Qatari is showing as more economic in Figure 1.30

- Impact on Trading Portfolios: As the global LNG trade becomes commodified, with more liquidity for traders to work with, global players taking merchant risk will increasingly look to

\footnotetext{
28 "The Competitiveness of Canadian Natural Gas and LNG on a Global Scale". Used with permission. hittps://sproule.com/Ingwebinar.

29 Ibid. 27

${ }^{30}$ Capital cost estimates for trains 3 \& 4 and additional work required on the Coastal GasLink (CGL) pipeline to allow for the LNG Canada expansion are not public information and have been estimated as part of this paper based on project

development experience for similar projects in Canada and around the world of the author.
} 
wield a portfolio of strategically placed supply sources across various geographies that are highly competitive on marginal costs, to have the upper hand in competitive trading. LNG Canada's proximate shipping distance to Asia was likely not lost on Shell's decision makers, who make capital decisions based on their global LNG portfolio.

- Financing: Because LNG supply sources arise in myriad fiscal and political regimes and require tens of billions of dollars in investment, a wide variety of corporate, private, projectlevel, and governmental financing structures, across numerous partners, are developed (even within the value-chain of a single project). Conversely, supply cost charts employ the simplifying assumption of a constant return rate, regardless of jurisdiction or investor type.

- Risk of delay or cancellation: With large discrete capacity additions of LNG reaching commercial operation dates (COD) in fits and starts, not meeting the target demand growth window for when a project hits COD because of delays can destroy project economics (especially at the $15-20 \%$ rate of returns typically required by merchant investors). The risk of outright cancellation prompts further apprehension. Investors are especially apprehensive about investing in Canada and the US (outside the USGC).

\section{Upstream: Canada's gas market glut should be more attractive to LNG investors}

Supply and demand drivers of the Canadian natural gas market are complex given the country is the world's fourth largest producer (17.9 bcfd in 2018) with a population that snuggles up closely to the $8,900 \mathrm{~km}$ (5,600 mile) border it shares with the US, the world's largest gas consumer (79 bcfd) and, since the advent of shale gas, its largest producer ( 80 bcfd). ${ }^{31,32}$

Figure 2: Major Canadian natural gas pipelines and capacities

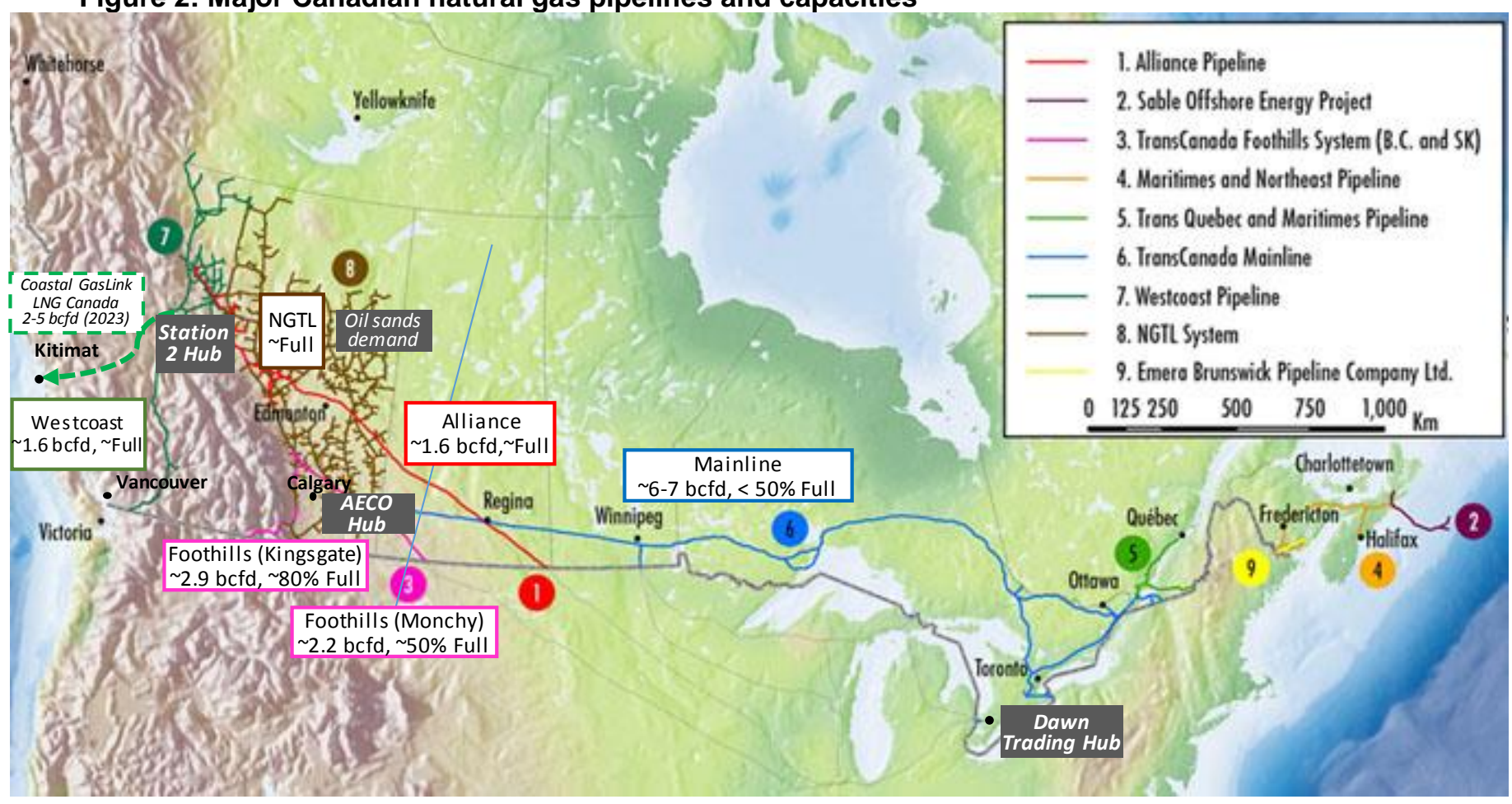

Source: National Energy Board (2016) and Criterium Group / OIES

The OIES summarized these complex market factors in 2015; indeed, many of these ongoing dynamics merit their own dedicated research paper. ${ }^{33}$ The present paper rather, discusses how Western Canada's feedgas supply impacts Canadian LNG competitiveness versus other producing regions.

\footnotetext{
${ }^{31}$ BP, Statistical Review Of World Energy, All Data 1965-2018, 2019.

32 It is estimated that 85-90\% of Canada's population lives within $160 \mathrm{~km}$ or 100 miles of that border.

${ }^{3} 3$ Ieda Gomes, Natural Gas In Canada: What Are The Options Going Forward? (Oxford: Oxford Institute for Energy Studies, 2019).
} 
Canada's natural gas production is historically centred on Alberta, in the core of the Western Canadian Sedimentary Basin (WCSB). ${ }^{34}$ Production contributions from neighbouring provinces British Columbia (west) and to a lesser extent Saskatchewan and Manitoba (east) have increased due to growth in light tight oil (LTO) and gas production from shale reservoirs - the Montney play, which straddles the BCAlberta border is now producing roughly $7 \mathrm{bcfd}$. Much of future production growth is predicted to occur on the BC side, where well economics are, on average, more attractive. Whereas the rapid growth in gas production US shale plays has been spurred by prodigious capital investment and easy access to markets, growth in the Montney is driven by the size of resource (roughly 450 tcf) that offers security of supply and long-term upside, a lower environmental footprint per volume of reservoir tapped, and liquids rich production (combined with a strong local market for LTO and condensate).

Infrastructure has been built over generations to ensure adequate gathering in the core producing region (TC Energy's NGTL system) and egress from the WCSB towards more populous markets in Eastern Canada and the US. Several of Canada's core gas transmission pipelines, mapped in Figure 2 , have been running at low utilization - most glaring is the 3-4 bcfd of spare capacity in TC Energy's capacious Mainline. As one might guess, the culprit for this suboptimal utilization is the disruptive arrival of US shale gas, initially spewing out of the Northeast US but increasingly from the Rockies and the Permian basin, with the net result being a shrinking demand for Canadian gas.

\section{Figure 3: Impact of shale gas production on North American Gas supply and demand}

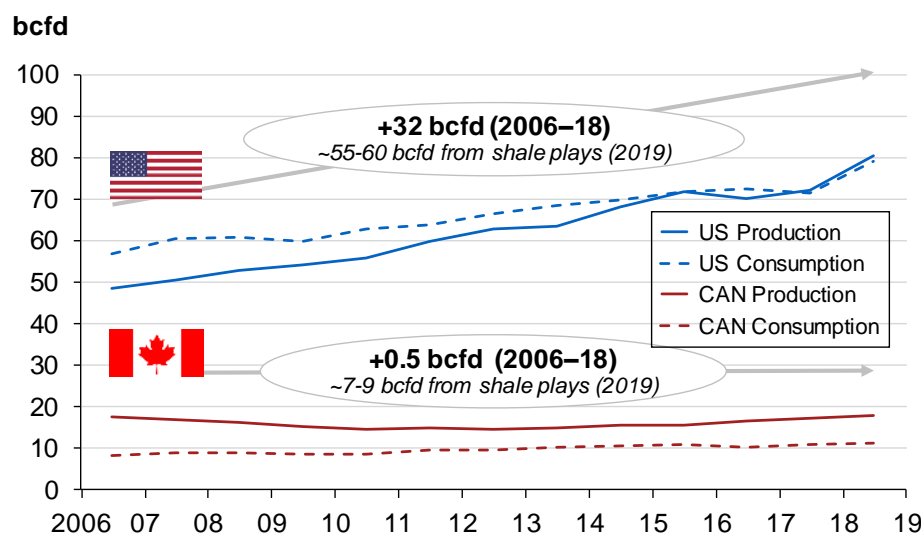

Source: BP Statistical Review (2019), Oxford Institute for Energy Studies / Criterium Group, EIA (for US shale estimates), AltaCorp Capital / GeoScout (for Canadian shale estimates)

The near- and long-term impacts of large-scale US shale reservoir production on Canadian gas markets, highlighted in Figure 3, cannot be understated. The US shale boom has obviated net imports for the US, Canada's only gas export customer (one that had a large appetite and shrinking domestic production). But as in the US, the shale revolution unlocked vast, previously inaccessible reserves that could enable Canada to be a cornerstone global LNG supplier, and even spur a petrochemical renaissance. The key difference here is that the US actually capitalized on this opportunity to effectuate transformational growth, generating an incremental 32 bcfd gas production, more than $\$ 200$ billion in petrochemical investment, and $117 \mathrm{mtpa}$ of sanctioned LNG projects, with significantly more that have finished Front-End Engineering Design (FEED) and are close to FID. ${ }^{35}$ Meanwhile, once audacious growth plans for Canadian gas production, petrochemical development and LNG export have sputtered, adding only a paltry $0.5 \mathrm{bcfd}$ net production (shale growth has offset conventional declines), \$7-9 billion petrochemical investment, and $13 \mathrm{mtpa}$ of sanctioned LNG export (all of which is from LNG Canada's first phase, not online until 2023). ${ }^{36}$

Indeed, the US position on gas exports took some political muscle to overturn the banning of exports for energy security reasons. As shale basins are seeing less investment due to poor returns, might a future US government change its view of exports and revert to the paramountcy of "energy security", especially if gas emerges as the dominant fuel for power generation? The geopolitics of hydrocarbon

\footnotetext{
${ }^{34}$ A small fraction of Canada's gas production occurs off its eastern coast.

${ }^{35}$ American Chemistry Council (2019), EIA Liquefaction Capacity (Sept 2019)

${ }^{36}$ Only two major petrochemical plants have been sanctioned in Alberta's Industrial Heartland region: both are PDH-

polypropylene complexes, and each is considered smaller than world-scale.
} 
markets dynamics are difficult to predict more than a decade out, least of all the tenets of US energy policy.

Certainly, the USGC benefits from some innate advantages — primarily a greater domestic demand to supply; brownfield installations for petrochemical and LNG; fully developed natural gas liquids (NGL) markets; larger labour pools in proximity to the developments; less regulatory delay and uncertainty; and a more dynamic business environment overall. Nevertheless, the US domination of Canada for the spoils of the shale gas revolution has remarkably occurred while Canadian natural gas and NGLs have been much cheaper. Besides, LNG development in the USGC faces its own challenges: Panama Canal constraints, hurricane risk, unresolved US trade wars with China, and an overall bloat in construction driven by LNG, petrochemical and other developments that chokes the labour pool.

\section{Figure 4: Price history and outlook for AECO and Station 2 vs. Henry Hub}

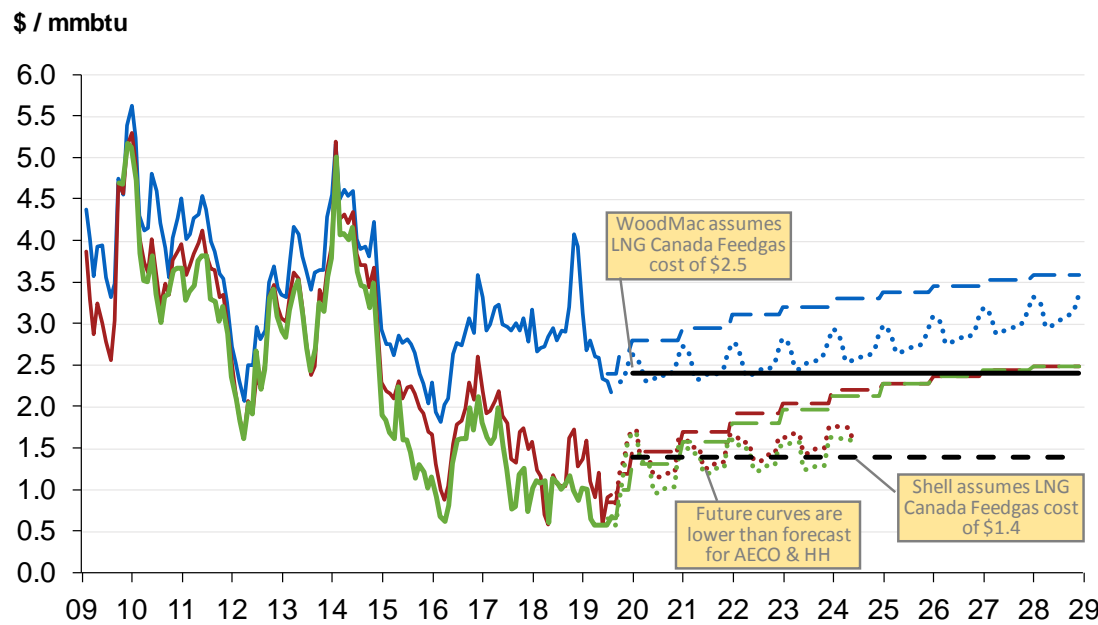

$$
\begin{aligned}
- & \text { Henry Hub } \\
\ldots . . & \text { HH Forward } \\
- & \text { HH Forecast } \\
- & \text { AECO } \\
\ldots . . & \text { AECO Forward } \\
- & \text { AECO Forecast } \\
- & \text { Station } 2 \\
\ldots . . & \text { S2 Foreward } \\
- & \text { S2 Forecast } \\
- & \text { WoodMac Estimate } \\
& \text { (LNG Canada) } \\
- & \text { Shell Estimate } \\
& \text { (LNG Canada) }
\end{aligned}
$$

AECO as (\%) of Henry Hub

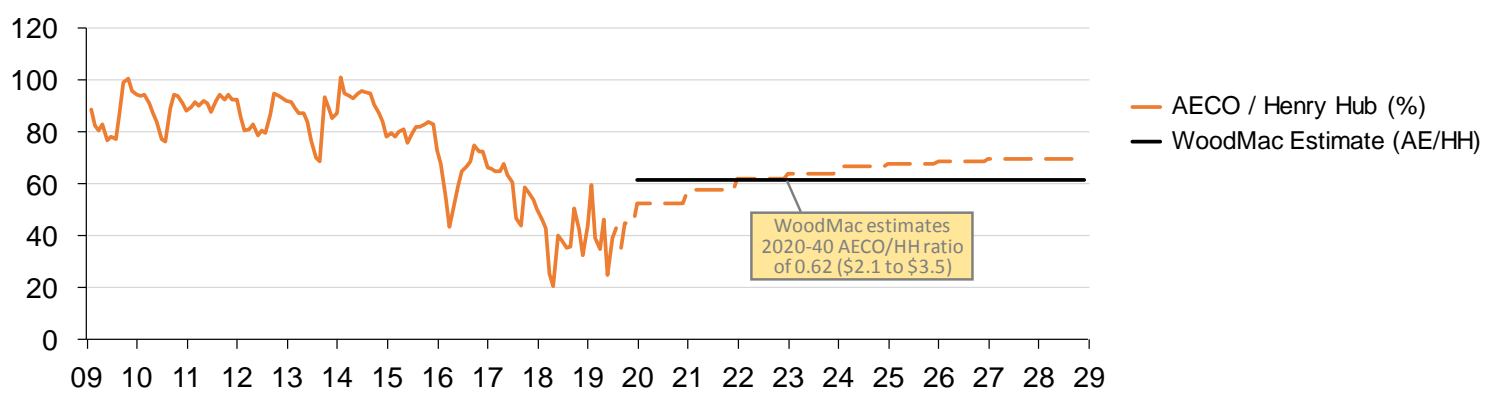

Source (with permission): GLJ Petroleum Consultants Price Decks, Wood Mackenzie ${ }^{37}$

Also on the North American LNG radar, Mexico has access to low-cost USGC gas, especially associated gas from the LTO-prolific Permian, and could be a competitive option for export to Asia. Shipping from Mexico's West Coast saves 10 days or more compared to the USGC by avoiding the Panama Canal. In March 2019, Sempra Energy's subsidiary Energía Costa Azul (ECA) LNG received approval from the US Department of Energy to export US produced natural gas to Mexico and to reexport LNG to countries that do not have a free-trade agreement with the US. ${ }^{38,39}$

Fundamentally, investors feel that North America will continue to have a glut of natural gas, especially with so much associated gas emanating from LTO and wetter gas plays (even if shale investment is showing signs of slower growth, below expectations.) Within this continental context, Canadian gas is challenged to find a demand sink. ${ }^{40} \mathrm{AECO}$ and Station 2's downward price spiral is caused by less need for WCSB gas in central Canada and its other traditional markets, congestion in TC Energy's

\footnotetext{
37 Ibid. 27

${ }^{38}$ Sempra Energy Press Release, Energía Costa Azul LNG Website, 2019, http://www.ecalng.com.

${ }^{39}$ Mexico Pacific Limited (MPL) is also a proponent project of Mexico's West Coast.

40 Of course, so is Canadian oil, whose production has been heavily depressed by lack of export pipelines, rather than demand.
} 
NGTL gathering system, and producers growing associated gas from condensate production - WCSB gas production has increased significantly in the past few years despite less overall demand for it. Diluent (condensate and pentanes-plus) has been the most valuable of WCSB's hydrocarbons and its demand in Northern Alberta continues to grow with oil sands production, even though oil sands growth has been temporarily shackled by a lack of pipeline takeaway capacity (leading to an Alberta government-imposed curtailment in late 2018). ${ }^{41}$ Growth is expected as new phases and debottlenecking continue. ${ }^{42}$ Demand for locally produced diluent has shielded the balance sheets of Canadian gas producers (at least those not beholden to dry gas production) from solvency challenges and will continue to enable production of natural gas at remarkably low, potentially even negative prices over coming decades. (Negative prices have been seen on some days recently). ${ }^{43}$ Most WCSB gasfocused producers are moving towards the production and revenue profile of Seven Generations, one of the basin's larger gas producers. Summarized in Figure 5, its profile shows that in the quest for profitable condensate, NGLs and natural gas drive a disproportionately small amount of their netbacks. That said, like several other producers in the Montney, Seven Generations aims to market as little gas as possible off the AECO index, stressing instead that their price points are Dawn, Chicago, Malin, Henry Hub, etc. (Seven Generations is astonishingly selling gas to an LNG project more than 4,000 kilometres away in the USGC.) An upshot of this is that the drivers for current production may be different from future production (if NGL or gas prices increase, for example), and this could result in a contest between buyers as to who has the most market power.

Figure 5: Production vs. revenue split for Seven Generations Energy (Q2 2019)

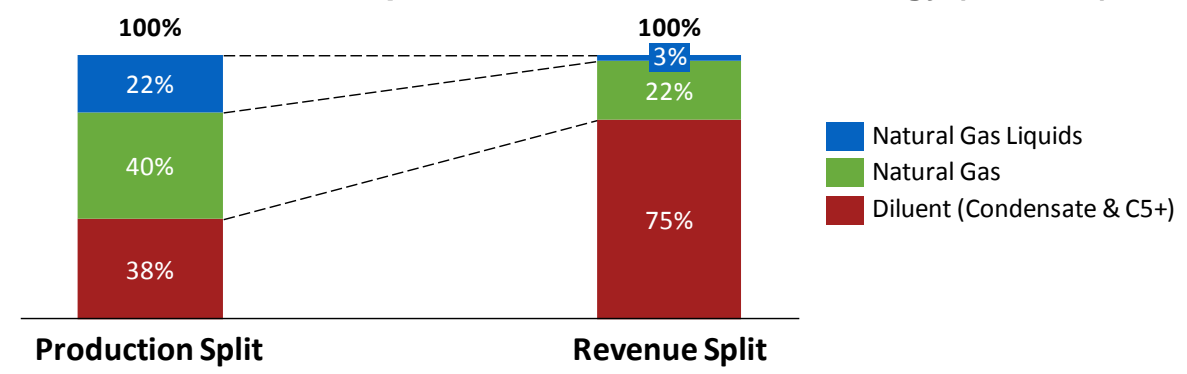

Source: Seven Generation Financial Reporting ${ }^{44}$

One can infer from Figure 5 that not only are Western Canada's natural gas markets flush, but so also are its natural gas liquids markets, where prices suffer from similar drastic discounts from USGC prices. NGLs have also strayed into negative pricing at times over the past few years - astute marketers with storage assets profit handsomely, while producers suffer. Such low prices have spurred NGL demand: two PDH-Polypropylene complexes currently under construction and 2-3 propane export facilities off the West Coast will support better propane prices for producers. Also, multiple petrochemical producers are probably considering building a new ethane cracker in Alberta, which would be the first in decades. ${ }^{45}$ Nevertheless, none have announced publicly any specific intention to build a cracker, let alone a timetable for FID.

The outlook for WCSB natural gas and NGL prices looks bleak over the next 4-5 years, at least until LNG Canada is operating and the propane market is buoyed by the new demand described above. Indeed, the future curves in Figure 4 show one can lock-in AECO gas purchases for $\$ 1-1.5 / \mathrm{mmbtu}$ until 2024 anyway. Beyond that, the apparent consensus among forecasters (such as Wood Mackenzie and GLJ in Figure 4) portends a recovery of the AECO / Henry Hub differential ratio: from 35-40\% today, to $60-70 \% .{ }^{46}$ But is that recovery realistic given:

\footnotetext{
${ }^{41}$ Diluent is blended with bitumen from Canada's oil sands to enable upgrading and/or transmission by pipeline.

42 See the latest CAPP production outlook: 2019 Crude Oil Forecast, Markets and Transportation

${ }^{43}$ Trident Exploration, Bellatrix Exploration and Calgary-based Houston Oil and Gas have either ceased operations or entered bankruptcy protection as of November 2019

${ }^{44}$ Production split is normalized by heat content (mmbtu); revenue split is total sales revenue, before transportation, royalties and operating expenses.

${ }^{45}$ From Alberta's second round of the Petrochemical Diversification Program (PDP), it is inferred by the publicly announced number of applicants that multiple proposals for ethane crackers were received, as was the intention of the program.

46 lbid. 27
} 
1) the unique local demand for oil sands condensate that will likely grow as Canadian production replaces US condensate imports,

2) seemingly inexorable shrinking of US demand for Canadian natural gas, and

3) that the WCSB has some of the most competitive well economics in the world?

Wood Mackenzie estimates that the Montney and Duvernay basins alone, have roughly 50 tcf of remaining risked reserves, enough for an LNG Canada sized plant (including its expansion to $26 \mathrm{mtpa}$ ) to run for 40 years, with an average break-even gas production cost of $\$ 0.4 / \mathrm{mmbtu}$ (at $10 \% \mathrm{IRR}$ ). ${ }^{47}$ From the same report, WoodMac estimates $100 \mathrm{tcf}$ (or $52 \mathrm{mtpa}$ for 40 years) is available at an average break-even production cost of $\$ 1.4 / \mathrm{mmbtu}^{48}$ Reservoir engineering consultancy Sproule estimates roughly $1 / 3$ of Montney areas have economics that are almost fully underpinned by oil and condensate production, where gas is produced effectively as a by-product, and the wells still break even with a standard rate-of-return assumption. ${ }^{49}$ It is important to note that integrated investors (like most partners in LNG Canada) are not beholden to pay AECO or Station 2 index prices for gas, but a transfer price from their upstream operations, which could be at a break-even at $\$ 0.40 / \mathrm{mmbtu}$ or less if they are also producing condensate. (That said, because index pricing has been so cheap, LNG Canada partners will likely use a combination of their own, and NGTL purchased, feedgas supply.)

The dour natural gas and NGL price outlook has executives of WCSB producers clamouring for both governmental action and TC Energy investment to address infrastructure challenges and debottleneck the NGTL gathering system. But even if the pressing egress issues are resolved - to be fair, TC Energy is spending billions of dollars each year expanding NGTL — there needs to be a demand sink to repair low prices, an exit valve, as it were, for the whole system to achieve some value for the surfeit of gas in Western Canada. ${ }^{50}$ The system will need more redundancy to address supply security; who will end up footing the bill? This is why LNG development is such a core driver of the Canadian economy.

\section{Feedgas transport: A bridge too costly?}

While Canada is one of the world's most attractive LNG supply regions for feedgas cost, it is one of the least attractive for the cost of feedgas transport (before liquefaction). Unlike most other proponent regions (e.g. Qatar, Russia, USGC, West Africa), Canada's prolific gas basins are located hundreds of kilometres from the West Coast, as seen in Canadian LNG projects off the West Coast are burdened with a $\$ 0.7-1.1 / \mathrm{mmbtu}$ feedgas transport cost (depending primarily on the scale of the project), whereas the toll in the USGC is estimated between $\$ 0.15-0.40 / \mathrm{mmbtu}$ (depending more on location). For LNG proponents in Eastern Canada, unless they can siphon off low-cost gas from the US NE (challenging due to anti-pipeline activism in proximate states and provinces), their tolling cost to transport gas all the way from the WCSB to Quebec or Nova . (LNG Canada's Coastal GasLink, for example, is approximately $670 \mathrm{~km}$ in length.) Rather than a geographical LNG hub, where manifold pipelines terminate at or near the point of liquefaction, as in the in USGC, Canadian LNG proponents have developed relatively isolated projects on the West Coast that must plan and build their own pipeline through tortuous, mountainous routes. Land acquisition is not as simple as writing cheques, which is costly enough, but also requires consultation, thorny negotiations, and revenue sharing with a multitude of Indigenous groups that control the land along the right of way (ROW); for example, Coastal GasLink managed to negotiate a consensus among more than 20 First Nations along its ROW. (Despite this consensus, there is still stiff resistance from some of the First Nations arising from the difference between hereditary and elected chiefs - political dynamics can be complex.)

Canadian LNG projects off the West Coast are burdened with a $\$ 0.7-1.1 / \mathrm{mmbtu}$ feedgas transport cost (depending primarily on the scale of the project), whereas the toll in the USGC is estimated between $\$ 0.15-0.40 / \mathrm{mmbtu}$ (depending more on location). For LNG proponents in Eastern Canada, unless they can siphon off low-cost gas from the US NE (challenging due to anti-pipeline activism in proximate 
states and provinces), their tolling cost to transport gas all the way from the WCSB to Quebec or Nova Scotia is likely well over $\$ 2 / \mathrm{mmbtu}$, weakening their ability to compete for European markets. ${ }^{51}$ Moreover, the "cost of doing business" with pipeline operators in Canada is more than just the toll as they do not take the risk of development costs, usually hundreds of millions of dollars, which are shouldered by LNG project developers.

\section{Figure 6: Selected proposed feedgas pipelines for Western Canadian LNG}

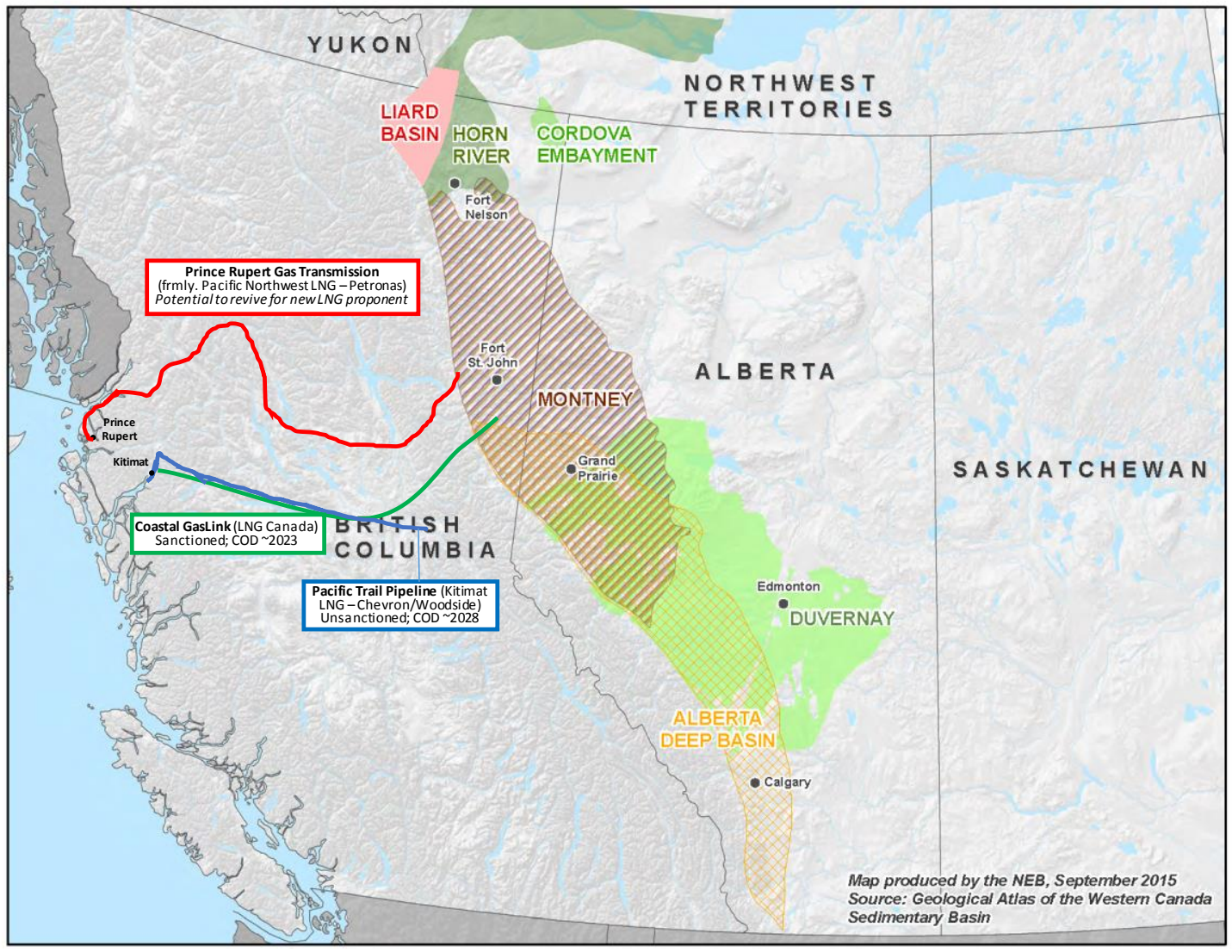

Source: National Energy Board / Oxford Institute for Energy Studies

Fortunately, changes to projects in the development phase can lower feedgas transmission costs. These include using already established ROW routes of previously laid or concurrently developed pipelines. Building larger scale transmission lines, even jointly with competitor projects, can generate significant savings: LNG Canada's expansion phase assuredly will have much lower per unit cost for feedgas transport than the original phase as the pipeline is already built.

More creative ways to finance this transmission portion of the value chain can also lower per mmbtu costs: if a project has capital commitments from highly credit-worthy investors (like supermajors, national oil companies, and LNG consuming utilities), low cost-of-capital pension, sovereign wealth, and private equity funds could be leveraged to generate economic value and make the overall project more competitive. ${ }^{52}$ The challenge is that whoever "rents" capital in such a fashion from lower cost of capital partners, will likely need to absorb a disproportionate amount of risk.

Finally, to further reduce transmission costs, the capital intensity of building these pipelines should be addressed; it will be addressed in the following section, as part of the liquefaction discussion.

\footnotetext{
${ }^{51}$ East Coast LNG proponents have been unable to overcome provincial aversion to shale gas production as Nova Scotia and Québec have de facto bans on hydraulic fracturing, while New Brunswick just relaxed their ban (to vehement protests).

${ }^{52}$ Case in point, TC Energy is working with RBC Capital Markets to find joint venture partners, assumedly with lower costs of capital, to own up to $75 \%$ of its Coastal GasLink pipeline that once built will supply LNG Canada.
} 


\section{Liquefying in Canada: Cold, if costly}

Freezing gas to below $-160^{\circ} \mathrm{C}$, decreasing its volume 600 times less than the space gas occupies at room temperature, is no easy feat - sizeable, capital-intensive assets and sizeable operating costs to power the chilling process and run the liquefaction plant are required.

Canadian proponents are highly competitive for operating costs. For generic LNG plants on the West and East Coasts of Canada, the Canadian Energy Research Institute estimates a full life-cycle operating cost of $\$ 0.69 / \mathrm{mmbtu}$, a $\$ 0.23$ saving from USGC projects and an astounding $\$ 0.65$ less than Australian projects. ${ }^{53,54}$ This discrepancy can be explained by:

- Climate-Related Efficiency: Liquefying gas in frigid climes is understandably easier than in balmy regions. Average temperature in Kitimat, $\mathrm{BC}$ is $7^{\circ} \mathrm{C}$, versus $22^{\circ} \mathrm{C}$ for Corpus Christi, Texas and $28^{\circ} \mathrm{C}$ for Darwin, Australia; differentials affect energy use and GHG emissions. Furthermore, inland gas transportation and liquefaction performance is better in the cold Canadian winter, when global markets increase their demand whereas Australia, US and Qatar benefit less. Russian LNG benefits similarly from its cold climate but struggles to reach Asia by ship through the North Sea route during winter months.

- Cost of Labour: Given the low value of the Canadian dollar and high demand for skilled operators in the USGC, ongoing operating labour is judged to be more competitive in Canada.

- Utilization: Panama Canal bottlenecks and hurricane season lead to increases in cost per mmbtu. Also, Canadian LNG plants will have higher utilization than USGC plants during potential price wars (supply gluts), due to the inherently lower marginal cost of production in Canada.

- Equipment and Infrastructure Specification: The onerous complexity of Australia's LNG production installations has contributed in the past to higher operating costs. ${ }^{54}$

Canada's material advantage in operating costs is however greatly overshadowed by its formidable liquefaction capital cost premium over the USGC (most estimates give a premium of $30-50 \%$ ), where the world's largest downstream, petrochemical and (soon-to-be) LNG export clusters offer established operating installations, infrastructure, regulatory clarity, competitive fiscal regimes and project development capability.

The remoteness and sparse population of Canada's West Coast make it an almost purely "greenfield" location. (Rio Tinto operates an aluminium smelter near LNG Canada in Kitimat, in many ways, a similar plant.) Though there has been some industrial activity in the past, proponents must build roads, bridges, services, and housing for workers, as well as fly skilled labour in and out with associated perquisites. Transport routes for large pieces of equipment, by ship or land, are more cumbersome than in the USGC. Figure 7 details the formidable capital costs LNG Canada faced in 2016, especially compared with lower cost competing brownfield projects in the USGC. The LNG Canada partnership challenged the project's high cost estimates, which were mostly made at a time of high oil prices, retendering their EPC contracts. The result was more a competitive capital cost estimate, with less contingency, given that the successful EPC suppliers (JGC and Fluor) were willing to share some of the overspend risk; this saved roughly $\$ 0.3 / \mathrm{mmbtu} .{ }^{55}$ Meanwhile, in an attempt to reverse the exodus of project proponents and investor interest to the USGC, the BC government decided to effectively cancel its rent-seeking BC LNG tax and provide further relief with Provincial Sales Tax (PST) exemptions on the purchase of certain capital equipment; this saved an estimated $\$ 0.15 / \mathrm{mmbtu} .{ }^{55}$

\footnotetext{
${ }^{53}$ Canadian Energy Research Institute, Competitive Analysis Of Canadian LNG, Series 172 (Calgary, 2018).

${ }^{54}$ Estimates for Australian LNG were based on this report from 2013: McKinsey \& Company, Extending The LNG Boom: Improving Australian LNG Productivity And Competitiveness, 2013. Improvements have likely been made since.
} 
Figure 7: Capital cost comparison for liquefaction (USGC vs. Canada)

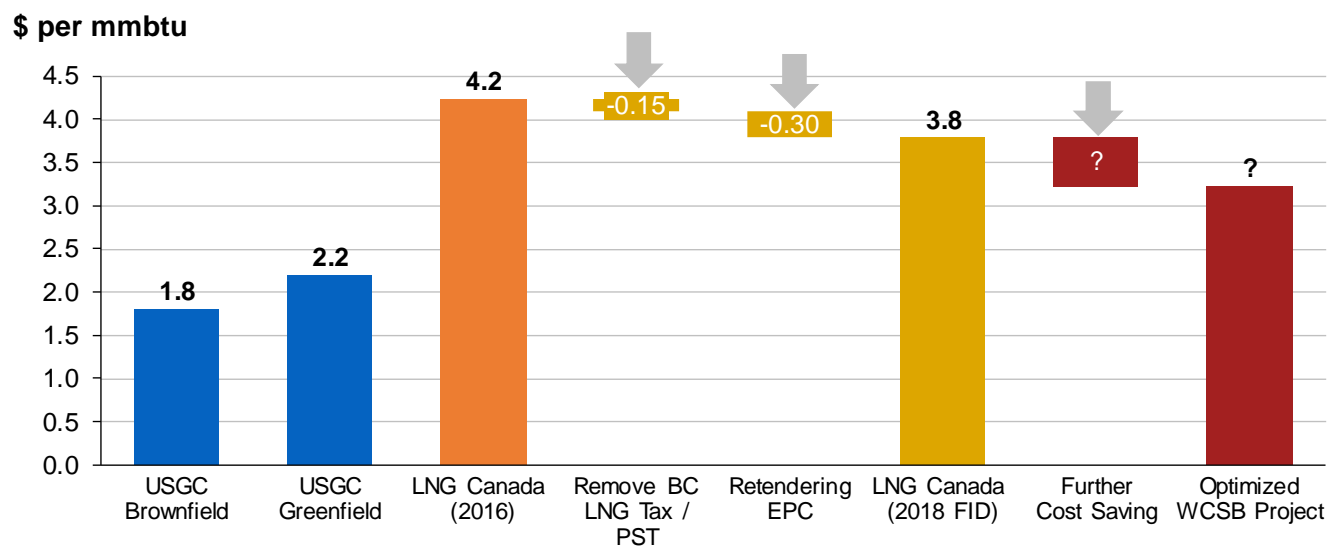

Source (with permission): Wood Mackenzie ${ }^{55}$ and Oxford Institute for Energy Studies

Even with those savings, the truly greenfield LNG Canada is estimated to be $\$ 1.5-2 / \mathrm{mmbtu}$ costlier for capital spend than a USGC brownfield build, and \$1-1.5 more than a USGC greenfield build. East Coast Canadian LNG proponents who propose somewhat less-remote locations struggle with a lack of scale. Canadian proponents are taking the following approaches to address the capital cost premiums:

- Increasing scale: Like projects in Russia, Qatar and West Africa, Canadian proponents could aim for larger scale LNG plants with expansion capability, to offset greenfield costs.

- Reconsidering configuration \& technology: Proponents have considered floating terminals (FLNG) to allow more overseas construction, though shoreline restrictions and climate have limited the idea. Steelhead's Kwispaa LNG, before it was shelved in early 2019, proposed an At-Shore-LNGTM design based on substantially reducing capital costs/mtpa.

- Joint cost-cutting with EPC partners: Project owners and EPC partners work together, before and after the bidding process, to find savings and reduce contingencies through planning improvements and better capital project execution.

- Collaborating with unions: Compared to the USGC, proponents in BC must contend with a more unionized workforce. Proponents can work with the unions to address cost challenges to enable growth of a BC LNG industry, something unions ardently support.

- Negotiating with governments: As projects in the USGC multiplied and flourished those on BC's West Coast stumbled and ceased, the federal and BC provincial governments began to realize that they needed to bolster the competitiveness of Canadian LNG. Removing the LNG tax (BC), reducing the PST burden (BC), ensuring steel tariffs would not be imposed by the US (federal), and allowing an increased capital cost depreciation allowance (federal) have helped. But overall, the incentive and tax fiscal regime has not allowed Canada to compete with the USGC. Otherwise, Canada would have $100 \mathrm{mtpa}$ of sanctioned LNG projects, rather than $13 \mathrm{mtpa}$. This is not just for LNG either; petrochemical investment in the USGC, which indirectly supports LNG growth through a strong market for NGLs, has dwarfed that in Canada by more than a factor of 20 .

The question is then: How much ground can be made up versus the more capital efficient US projects? LNG Canada's construction in the next few years may yield some answers. Regardless of how attractive the LNG to feedgas price spread is, it is difficult to overcome a formidable capital cost premium due to the time value of money, potential overspend, and 5-7 years construction time - the Chevron-led Gorgon LNG Project is a paragon of this hard truth.

55 Wood Mackenzie, The Economics Of Canadian LNG: Can We Do Better?, 2019, https://www.woodmac.com/reports/gasmarkets-the-economics-of-canadian-Ing-can-we-do-better-312208. Used with permission. USGC Brownfield estimate made by author based on various sources including Wood Mackenzie and CERI. 


\section{Shipping LNG from Canada: Ideally located}

LNG shipping costs from Canada's West Coast to Asia are approximately $\$ 1.0 / \mathrm{mmbtu}$ lower than from the USGC (and roughly $\$ 0.3$ cheaper from Canada's East Coast to Europe), as exhibited in Figure 8. To be sure, only Australian-supplied LNG will cost less to ship to Asia, than LNG from Northwest BC, and just slightly. Not only does supply from more proximate locations lower shipping costs, it also reduces GHG emissions for the entire value chain; this will be further considered in the next section on ESG. The OIES addressed global LNG shipping costs in more detail in March $2018 .{ }^{56}$

With recent global LNG FIDs, we have seen however that high shipping costs, like all other cost components, can be overcome if the overall supply cost stack is still competitive; the sanctioning of Russia's Arctic LNG-2 is an example of this.

Figure 8: Shipping Costs of various LNG supply regions (\$ / mmbtu)
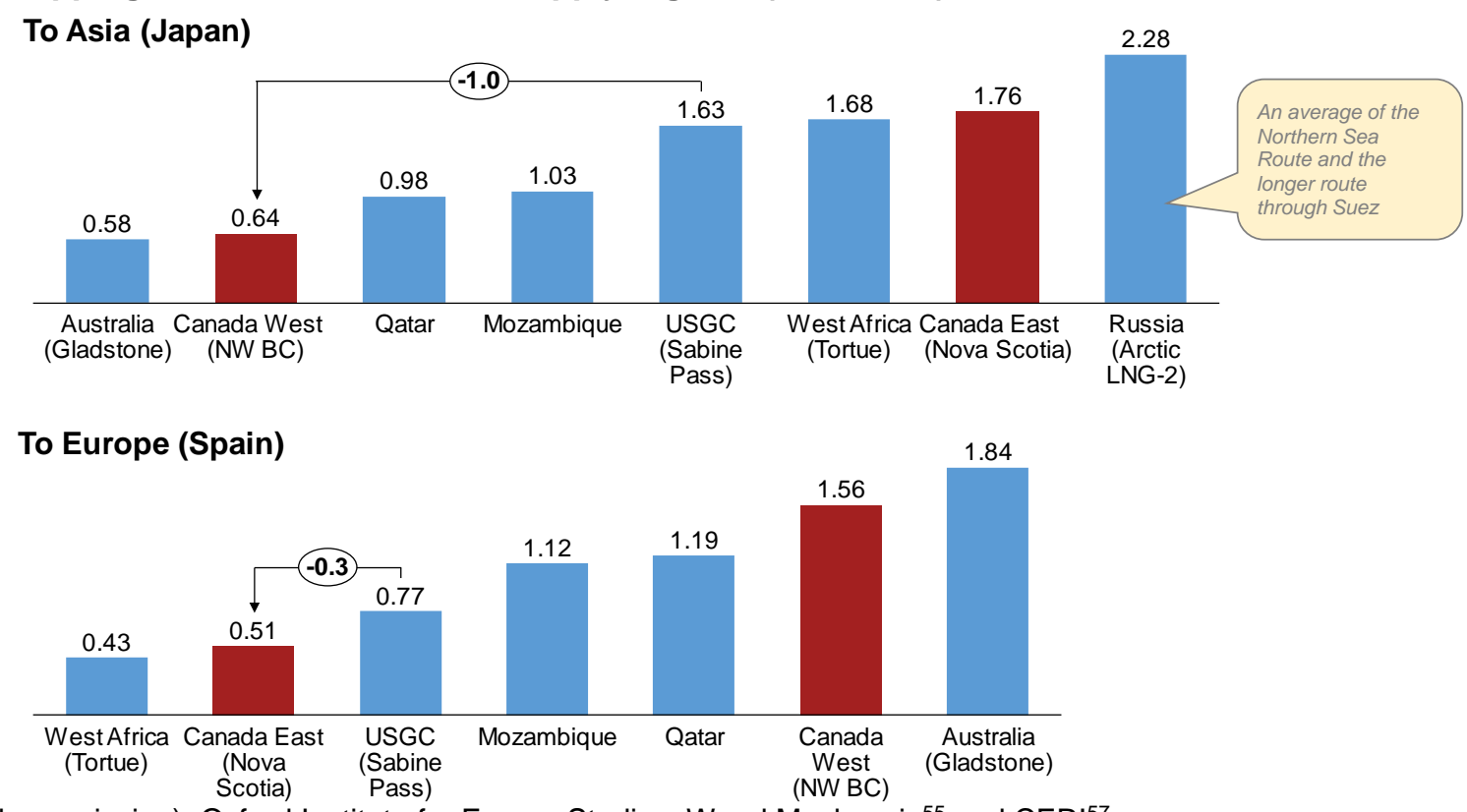

Source (with permission): Oxford Institute for Energy Studies, Wood Mackenzie ${ }^{55}$ and CER $\left.\right|^{57}$

\section{How Canada offers the most ESG value to LNG investors}

The extent to which Environmental, Social, and Governance (ESG) concerns impact the flow of capital investments of billions of dollars toward myriad global energy megaprojects is debatable - various research reports and capital markets experts have differing views. It is difficult to debate however, that the relevance and impact of these ESG concerns is not increasing.

The mushrooming global LNG market acts to reduce global emissions and air pollution, while also alleviating the historic geopolitical dependence that gas importing nations suffer from, in the grip of gas exporting neighbours who are connected by pipeline. ${ }^{58}$ Within that context of gas growth being beneficent for the world, this paper argues that Canadian LNG offers the most compelling overall ESG story to investors, among all global LNG proponents. This advantage, if properly communicated, should effectively increase Canada's overall competitiveness in the eyes of an ESG-concerned investor.

\section{Environmental: The greenest LNG value-chain in the world gets greener}

Natural gas is often touted as the indispensable necessary "bridge fuel" of the energy transition. But the extent to which gas can reduce global GHG emissions through aiding the development of

\footnotetext{
56 Howard Rogers, The LNG Shipping Forecast: Costs Rebounding, Outlook Uncertain, (OIES, 2019).

57 lbid. 53

58 This is especially salient in Europe, where the geopolitics of gas security have made Russia considerably more puissant.
} 
intermittent renewable power sources and replacing coal as a fuel source (which also will significantly reduce premature deaths from air pollution) varies, depending on:

1. Local availability and cost competitiveness of natural gas (domestic, pipeline and/or LNG)

2. Volume of methane released across the gas value-chain (from gas well to burner tip)

3. Emissions incurred from production, transmission, and, if LNG, liquefaction, shipping, regasification and secondary transmission

For example, the well documented US shale gas boom has led to more than 500 million tonnes of annual $\mathrm{CO}_{2}$ reduction and accounts for just less than one-fifth of all emissions reductions since 2010 in the US - roughly the same amount as for the addition of all renewables in that time. In this case, gas became locally available often at a lower cost/kWh than coal, and emissions in transporting the gas (by pipeline) were de minimis. (It is important to note however, that current flaring in the Permian is rather substantial: Rystad estimates that 0.75 bcfd is currently being flared there, which negates the coal-togas switching benefits of roughly the equivalent 0.75 bcfd of gas used in power generation or 15 million tonnes/year. $)^{59,60}$

\section{Upstream and midstream: methane and electrification}

The farrago of fact and myth that dominates the LNG value chain methane release discussion (that usually arises with regard to coal-to-gas switching) is difficult to navigate. In North America and globally, adequate measurements are hard to come by. ${ }^{61}$ Methane release estimates from the gas value chain in the US vary between 0.4 and $1.7 \%$, with an average estimate of around $1.0-1.2 \%$, below the IEA estimated global average of 1.7\%; and well below the roughly $3.2 \%$ threshold needed to deliver a net GHG savings versus coal-fired turbines. ${ }^{62,63}$

In comparison, Canada appears to be in the vanguard in the fight to reduce methane release. Estimates of fugitive methane emissions from BC production for example range between $0.2-0.7 \%$ of production. (The BC government estimates $0.2-0.3 \%$ and at the higher end of the range, prominent anti-fossil fuel development activist group The Suzuki Foundation estimates $0.7 \%$.) ${ }^{64,65,66}$ For its Northeast BC Groundbirch operations, Shell estimates its methane emissions intensity is only $0.1 \%$. A 2018 life-cycle analysis done by the Puget Sound Clean Air Agency concluded that natural gas from U.S. producers could emit as much as eight times more methane than gas produced in B.C. It cited tighter regulations for drilling and natural gas processing in BC compared to the US. Amid a dearth of consistently performed studies, this paper cannot conclusively state that a Canadian LNG value chain emanating from the WCSB will have lower methane emissions than a USGC one, but the data that is available suggests that Canadian emissions are significantly lower than the US on average, and much lower than the global average $(1.7 \%)$.

How is it that using mostly similar unconventional production technology as in the US, Western Canadian producers have demonstrated reduced methane release? They for most the part use the latest technology and techniques to ensure minimal methane leakage and apply LDAR protocols, including airborne and satellite detection techniques. ${ }^{67}$ Experts also note that additional reductions are made through a process known as "green completions" - a method of capturing "blowback" and preventing venting when a well is first fracked and produced. $85 \%$ of the wells drilled in BC were green

\footnotetext{
${ }^{59}$ Using the rough assumption that coal generates double the GHG emissions as natural gas for the same power production 60 JWN Staff. "Permian Gas Flaring Reaches Yet Another High: Rystad". JWN Energy, 2019.

${ }^{61}$ This institute provided a thorough overview of the methane release issue in oil and gas across global producing regions: Chris Le Fevre, Methane Emissions: From Blind-Spot To Spotlight (Oxford Institute for Energy Studies, 2017).

62 "New Study Finds 'Very Low' Methane Leakage Rates From Marcellus Shale - EID Climate - A Project Of IPAA", EID

Climate - A Project Of IPAA, 2019, https://eidclimate.org/new-study-finds-low-methane-leakage-rates-marcellus-shale/.

${ }^{63}$ Note also that methane is also released in the production of coal and needs to be considered.

${ }^{64}$ Nelson Bennett, "Canada's LNG Sector Vulnerable On GHG Perception Without Better Methane Tracking | Carbon \& Sustainability | JWN Energy", JWN Energy, 2019.

${ }^{65}$ John Werring, "Fugitives In Our Midst: Investigating Fugitive Emissions From Abandoned, Suspended And Active Oil And Gas Wells In The Montney Basin In Northeastern British Columbia - David Suzuki Foundation", D. Suzuki Foundation, 2019.

${ }^{66}$ The credibility of the Suzuki Foundation is challenged by this paper in that David Suzuki has claimed that "fracked gas has a carbon footprint at least as bad as coal (because of fugitive methane release)"; this is patently false for most global gas production, and especially Canadian gas production.

67 "Canada's Methane Regulations for The Upstream Oil and Gas Sector", 2019. https://www.canada.ca/en/environmentclimate-change/services/canadian-environmental-protection-act-registry/proposed-methane-regulations-additional- 
completions in $2017 .{ }^{64}$ Furthermore, parts of the Montney have become electrified with hydroelectricity. This both reduces GHG emissions by displacing the combustion of natural gas, and also further reduces methane release: producers install electric actuator valves instead of pneumatic ones that release natural gas each time they are activated. (This is partially how Shell reaches their $0.1 \%$.)

Today, BC and Alberta are arguably the most progressive gas producing jurisdictions in the world with regard to fugitive methane reduction, and more proactive than the US. This gap is likely to widen since the Trump administration weakened US methane regulation, while Canada has accelerated its government-sponsored methane reduction initiatives. 68 (These target a 40-45\% reduction on 2012 release rates by 2025.) Several environmentally concerned Canadian producers have developed their own aggressive and technology-driven methane reduction programs that greatly outperform regulations, using the capability as a marketing tool for Canadian production. 61,69

Figure 9: BC LNG GHG for liquefaction versus other LNG supply regions

\section{$\%$ CO2 per tonne LNG}

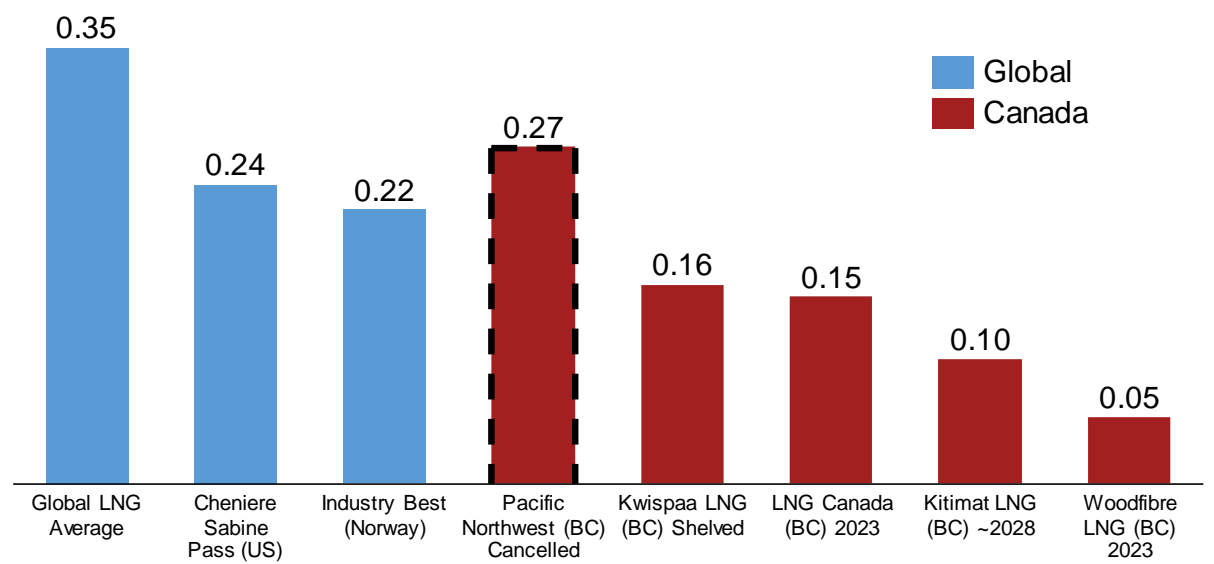

Sources: Project-Specific Canadian Environmental Assessment Act Reports, Kwispaa LNG website, Delphi Group 70

\section{Liquefaction \& shipping}

Figure 9 shows Canadian proponents to be trailblazers in reducing liquefaction emissions - LNG Canada is designed to be $32 \%$ more efficient than the current lowest emitting plant in the world. More sizeable emission reductions would accrue with Chevron \& Woodside's Kitimat LNG plans to drive their plants with electric motors that run on hydroelectricity. (The only other electric-drive plant in North America is the USGC's Freeport LNG, though Texas's power is approximately $75 \%$ natural gas and coal. $)^{71}$ At $2.1 \mathrm{mtpa}$, the now sanctioned Woodfibre hydroelectric-driven LNG plant will emit remarkably few emissions, though the plant is not considered world-scale. The IEA estimates that this electric "cleaner" LNG generates a 40\% reduction in GHG emissions from coal-to-gas switching (for the production of heat, anyway), versus only a $30 \%$ reduction with the industry-standard gas turbine powered LNG plants. ${ }^{72}$

In addition to controlling upstream emissions, Canadian LNG proponents tout their lower operating emissions than competitor regions by starting with colder gas, powering production and liquefaction with hydroelectricity (though only marginally for LNG Canada) and benefiting from much closer shipping distances to Asia (or Europe for East Coast proponents). (Note that electrifying the entire liquefaction process does add capital expense, as the hydroelectric sources will require turbine backup generation.)

For total emissions across the LNG value chain, but before final combustion, the Canadian Association of Petroleum Producers (CAPP) claims, with government data sources, that USGC LNG destined for

\footnotetext{
${ }^{68}$ Susan Noakes, "Methane Emissions Rules In U.S. Play Catch-Up With Alberta", CBC, 2016.

${ }^{69}$ For example, Modern Resources, a Canadian independent producer, recently won awards from Global Petroleum Show and the Daily Oil Bulletin for its Modern Ultra Low Emissions (MULE) sites aimed at reducing methane emissions to zero.

${ }^{70}$ Delphi Group, LNG Production In British Columbia: Greenhouse Gas Emissions Assessment And Benchmarking, 2013.

${ }^{71}$ See EIA website for "Texas Net Electricity Generation by Source"

72 International Energy Agency, The Role Of Gas In Today's Energy Transitions, 2019
} 
Asia is expected to emit more than double that for Canadian LNG (0.79 tonnes $\mathrm{CO}_{2, \text { eq }}$ per tonne versus 0.36 , respectively).

For the most comprehensive study of full value-chain emissions from gas well in Western Canada to burner-tip in Asia, including projected fugitive methane emissions, Stanford University, the University of Calgary, and the University of British Columbia decided to each perform an independent analysis. Figure 10 highlights the environmental benefits that BC LNG delivers for power generation, from Canada to Asia, when compared with other fossil fuels.

Figure 10: Full-value chain analysis of GHG Emissions from BC LNG, consumed in China

\section{Electricity Generation}

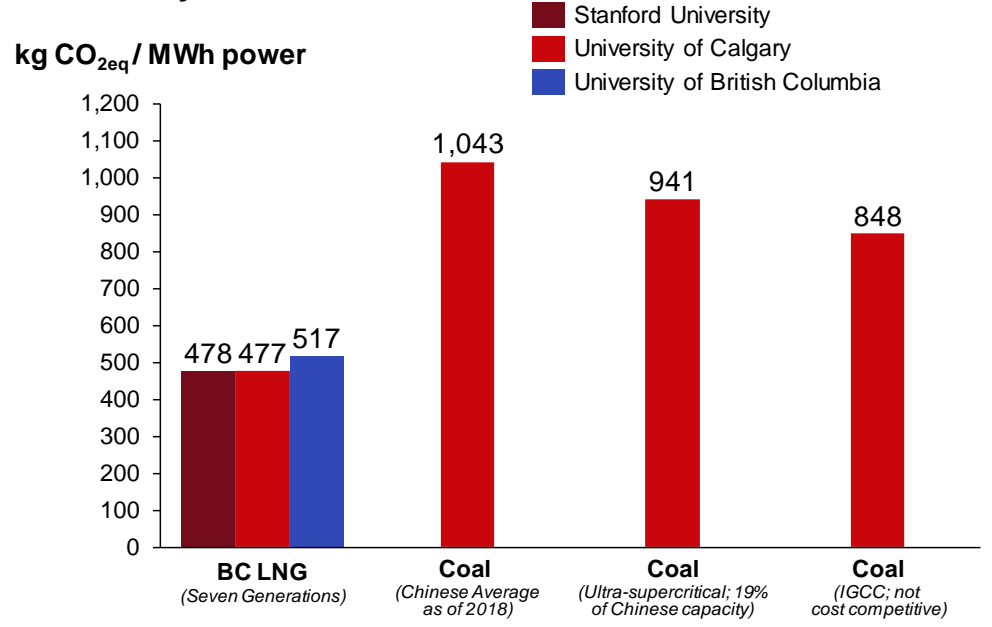

\section{Heating}

$\mathrm{kg} \mathrm{CO}$ 2eq $/$ GJ Heat

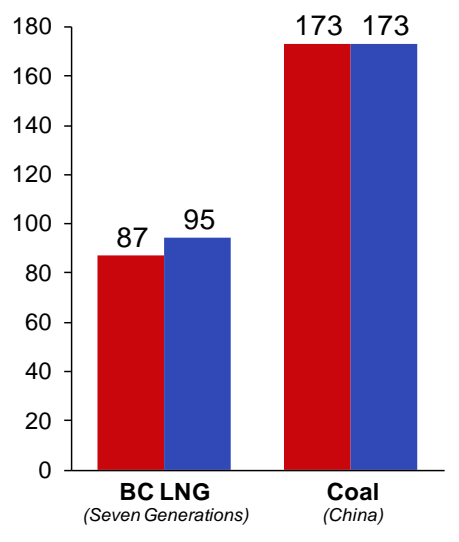

Sources: NGI Annual Affiliates Meeting and Research Review, 2018; ${ }^{73}$ Institute for Energy Research (for Chinese coal proportions by plant type $)^{74}$

\section{Social: Indigenous economic development}

Those familiar with Canadian history know that many of Canada's Indigenous peoples have at times been treated highly unfairly - their culture and way of life denigrated and disregarded. ${ }^{75}$ Many Indigenous communities in Canada face a lack of economic opportunity in their communities; poor access to essential services, even clean water; and social problems relating to crime and addiction at alarmingly higher rates than national averages. LNG development offers these mostly remote communities meaningful and sizeable opportunities for local employment, infrastructure, entrepreneurship, skill development, and cultural protection. (Many contractors and suppliers to major resource projects in Canada today are Indigenous-owned.) Four First Nations on the coast of Northeast BC are banding together through the "First Nations Climate Initiative" to support global GHG reductions through LNG. ${ }^{76}$ Conversely, some Coastal First Nations have relied on marine resources for centuries, some of which are self-provident and do not feel the need for industrial development.

The issues surrounding the impact of natural resource development on Canada's Indigenous peoples are highly complex. This paper only notes that the impact on First Nations is a key consideration, that the Canadian government's duty to First Nations, especially with respect to consultation and accommodation, and the "adequacy" thereof, still contain difficult issues notwithstanding a series of Supreme Court cases that have progressively attempted to define these concepts.

\footnotetext{
${ }^{73}$ Bergerson, Joule, Xiaotao Bi, and Adam Brandt. "Life Cycle Assessment Of Kakwa-Dervied LNG To China For Power Generation And District Heating". Presentation, NGI Annual Affiliates Meeting, 2019. Studies may not yet have been peer reviewed, but outputs between three independent universities are similar.

${ }^{74}$ Institute for Energy Research. Is Coal In China Dead?, 2019.

${ }^{75}$ Most salient and emblematic of past mistreatment were the government-funded, church-run Residential Schools. The initiative started in 1867 with an aim to "civilize and Christianize" many of the nation's Indigenous communities. For more than 125 years children were tragically removed from their parents and home communities to attend schools under horrid and often abusive conditions. Readers can gain an appreciation of Indigenous peoples' struggles by referring to Truth and Reconciliation Commission of Canada, TRC Final Report, 2015. and Thomas King, The Inconvenient Indian, 2013.

${ }^{76}$ Jang, Brett. "Indigenous Leaders Back LNG Exports As A Way To Fight Climate Change". Globe And Mail, 2019.
} 
Project developers are learning that it is worth granting Indigenous communities a "seat at the table" and potentially equity ownership in the project in order to earn their trust and support. Even with this, projects are certainly not immune to vociferous Indigenous detractors from multiple First Nations.

Though other global LNG projects have and will continue to create economic opportunity for disadvantaged local communities (Papa New Guinea and African projects are examples), Canadian projects are somewhat unique in that they involve many different Indigenous cultures, as any Western Canadian project will cross many First Nations communities along the $600-700 \mathrm{~km}$ pipeline.

LNG Canada's early consultation and engagement with Indigenous communities at the liquefaction site in Kitimat and all along the Coastal GasLink ROW exemplifies how resource development consultations can be transparent and mutually beneficial rather than confrontational. Steelhead LNG's Kwispaa project and other project proponents have learned from LNG Canada's trailblazing and propose even more inclusion and collaboration. Testament to what LNG development means for Indigenous communities, an open letter of support from Haisla First Nation is appended to this paper.

Apart from Indigenous development, Canadian companies are among the world's more proactive with regard to workforce diversity and generating opportunity for minority groups. ${ }^{77}$ Canada is revered for its willingness to welcome and successfully integrate immigrants (all four major political parties belabour the importance of immigration and diversity). ${ }^{78}$ Capital-intensive resource projects, such as those seen in the investment boom in the remote Canadian Oil Sands from roughly 2004-2015, provide many new Canadians - both skilled and unskilled - highly remunerated employment and an easier path to citizenship. For other social elements such as the UN Global Compact, UNDRIP, health \& safety, human \& labour rights, and contribution to stakeholders in broader society, Canadian producers and midstream operators are among the most progressive among global supply regions and are in-line with expectations of the Canadian public.

\section{Governance: Transparency, democracy, and free trade}

One might infer from the ongoing political imbroglio surrounding Canadian pipelines, caused by a much needed and majority-supported twinning of the Trans Mountain pipeline, that the country's political system is rather feckless - this will be addressed in the following section. Nevertheless, Canadians benefit from one of the world's more stable governments and longest running democracies; among countries with populations as large, only the British and American democracies are older. Its loyalist early beginnings continue to beget a moderate, if complacent, political ethos. Canada has not recently fallen prey to significant populist, anti-immigrant, or anti-trade tendencies, unlike the US and much of Western Europe. Moderation and restraint also underpin the country's financial institutions and central bank, both of which emerged effectively unscathed from the 2008 financial crisis in contrast to other OECD nations.

Transparency International ranks Canada with the lowest perception of corruption among all competitor LNG proponent nations (Table 1), though the country is certainly not immune to transgressions. ${ }^{79}$

\footnotetext{
77 See Forbes Insights: Knutson, Clara. "Top 10 Countries with Diverse Labor Forces", 2012.

${ }^{78}$ See the 2019 election platforms of the Liberal Party, the Conservative Party, the New Democratic Party and the Green Party.

${ }^{79}$ Quebec-based global EPC firm SNC Lavalin has been embroiled in a Libyan bribery scandal that was unearthed as part of the toppling of the Ghaddafi-led government. To further exacerbate the improbity associated with this scandal, Prime Minster Justin Trudeau was found in 2019 by Canada's Ethics Commissioner to have contravened the Conflict of Interest Act by applying pressure on Canada's Attorney General to broker a deal with SNC Lavalin, in a purported effort to avoid job losses in Montreal. Due to this scandal, and the uncovering of the considerable money laundering that sullies the nation's urban real estate markets, Canada may drop in the Transparency International's 2019 ranking.
} 
Table 1: Transparency International's Corruption Perception index 2018

\begin{tabular}{|c|c|}
\hline $\begin{array}{l}\text { LNG Supply } \\
\text { Country }\end{array}$ & $\begin{array}{c}\text { Rank (out of 180) } \\
\text { High = Less Corrupt; Low = More Corrupt }\end{array}$ \\
\hline Canada & 9 \\
\hline Australia & 13 \\
\hline USA & 22 \\
\hline Qatar & 33 \\
\hline Senegal (Tortue) & 67 \\
\hline Papua New Guinea & 138 \\
\hline Russia & 138 \\
\hline Mauritania (Tortue) & 144 \\
\hline Mozambique & 158 \\
\hline
\end{tabular}

Canadian (and likely Australian) LNG exports presently seem less prone to LNG trade-related geopolitics than the US given its recent quarrels with China - soon to be the world's largest LNG consumer. (However, Canadian-Chinese relations are currently at loggerheads over trade issues for agricultural products and the much publicized and contentious arrest of Huawai CFO Meng Wanzhou in Vancouver.)

Moreover, once an export license is granted in Canada, it cannot be revoked by the NEB, though the Federal Energy Regulatory Committee (FERC) has the power to do this to US LNG exporters. Overseas, Qatari and Russian LNG exports are fraught with sanction or embargo risk, potentially snared in geopolitical conflicts.

Canada seems more immune to extreme political movements than the US. On the right, the Trump Administration promulgates his intent to remove virtually any impeding regulation to fossil fuel development (such as methane regulation), whereas on the left, three of the four leading Democratic primary presidential candidates have vowed an abrupt end to "fracking", if elected. ${ }^{80}$ In Canada, the left-leaning, progressive federal Liberals and BC New Democrat Party at least feign support for the development of LNG - though one might argue the stasis in Canadian resource development has been aided and abetted by operatives in the Prime Minister's Office, and that this itself constitutes an "extreme political movement". ${ }^{81}$ Canadian conservative politicians generally support what they deem "sensible" oil and gas regulation, and are then wont to tout that Canada is among the best regulated producing jurisdictions in the world.

\section{How Canada creates its own hurdles and risks to LNG development}

\section{Regulatory and Indigenous relations: Onerous complexity}

The Canadian LNG project approval process is convoluted. Until the summer of 2019, projects required an export license from the National Energy Board. More challenging was passing a BC Environmental Assessment Agency review (under the Canadian Environmental Assessment Agency act) and earning a BC Oil and Gas Commission's permit for export. Each of these took several years and were highly complex. ${ }^{82}$ LNG Canada's environmental assessment and export permit, awarded in 2015 after 4-5 years of project development, was caveated with 54 conditions proceeded roughly as per plan - they were able to manage the external issues such that the contentious ones were taken off the critical path. In addition, proponents have a "Duty to Consult" all impacted Indigenous groups near the liquefaction facility and along the pipeline ROW - a process that also takes several years. All of this is required before FID. ${ }^{83}$ (It should be noted that long lead times for LNG export developments are common around the globe, though these early stage development costs are much higher in Canada.) Indigenous relations in BC are particularly complex because First Nations and Metis land rights are not under the dominion of broader, amalgamating treaties (like in other Canadian provinces) and distinct agreements

\footnotetext{
${ }^{80}$ Elizabeth Warren, who leads several national Democratic primary polls as of the fall of 2019, has also put forward a bill banning the blocking of construction in ports aimed at exporting natural gas.

${ }^{81}$ Only the relatively inconsequential Green Party is committed to a ban on hydraulic fracturing.

82 This is for Canadian West Coast projects.

${ }^{83}$ LNG Canada started development around 2011 and was approved for FID in 2018, for an expected COD of 2023.
} 
are therefore required with each group. ${ }^{84}$ Furthermore, court challenges regarding requirements cause costly, lengthy, and at times insurmountable delays for proponent projects, leading to wasted project development costs. Some of the costliest dead ends include the following list; it is important to note that some of these projects were guilty of poor project design or a lack of thorough consultation with Indigenous groups: 85

- Pacific Northwest LNG (Petronas-led): $\sim 750$ million in lost project costs

- Northern Gateway Oil Pipeline: $\$ 500$ million in lost project costs

- Energy East Oil Pipeline: $\$ 750$ million in lost project costs

- Trans Mountain Expansion Oil Pipeline: Still alive, though has required nationalization and suffered costly delays

In late November 2019, the BC government passed Bill 41 that enshrines the United Nations Declaration of the Rights of Indigenous Peoples (UNDRIP) into provincial law, highlighting that "free, prior and informed consent" in industrial development decisions is required. The impact of this is unclear as there are effectively no precedents to rest on for future legal challenges - a future supreme court challenge is likely. BC Premier John Horgan of the left-leaning NDP proclaims his perceived benefits of Bill 41, though others are more sceptical, claiming it will be a disabler rather than enabler of otherwise stymied development.86

Let's sit down with the title holders whose land we want to conduct economic activity on and create partnerships as a way forward. That works... Without UNDRIP, litigation is the way forward for investment. We've seen that with the Trans Mountain pipeline: court case after court case after court case.

With the spectre of crippling delays or writing off billions in development costs, independent developers — like Tellurian in the US, for example — cannot raise financing for Canadian LNG. Only supermajors, NOCs, massive investment funds and the largest infrastructure firms have the needed financial heft to invest.

To further complicate things Bill C-69, that Prime Minster Trudeau's government put into law in June 2019, overhauls what is arguably the world's most reputable energy regulator, replacing the National Energy Board (NEB) and the Environmental Assessment Agency (CEAA) with the new-fangled "Canadian Energy Regulator" and "Impact Assessment Agency", respectively, though Bill C-69 is much broader and includes much more than this. ${ }^{87}$ These departments are incrementally charged with evaluating hitherto unconsidered criteria for proposed projects: 88

\section{Canadian Energy Regulator}

- Health, social and economic effects, including the intersection of sex and gender with other identify factors

- The interests and concerns of Indigenous peoples

- The extent to which the effects of a pipeline would hinder or contribute to the government's ability to meet environmental obligations and climate change commitments.

\section{Impact Assessment Agency}

- The impact the project may have on Indigenous groups

- The project's contribution to sustainability

- The project's effect on the federal government's ability to meet environmental obligations and climate change commitments

- The intersection of sex and gender with other identity factors

Other global LNG proponents are generally not subject to such ill-defined, subjective requirements to gain approval. Naturally, Canada's oil and gas industry has vehemently protested Bill C-69's woolly

\footnotetext{
${ }^{84}$ The Indigenous Peoples of Canada consist of First Nations and Métis peoples.

${ }^{85}$ Viewpoint Group Research

${ }^{86}$ Larsen, Karin. "'We Are Moving Forward Together': Premier Urges Feds o Follow B.C.'S Lead In Enshrining UNDRIP". CBC News, 2019.

${ }^{87}$ Canada's Oil and Natural Gas Producers, International Review: Environmental Assessment Process - A Summary Based On The Review By Worley Parsons Canada, 2017.

88 "Senate Of Canada - The Impact Assessment Act In The Senate", Parliament Of Canada, 2019,

https://sencanada.ca/en/sencaplus/news/impact-assessment-act/. Accessed September 2019
} 
criteria and politicization, claiming the bill will add even more uncertainty to the regulatory process, further scaring off investors who have not already fled. Paraphrased below is a telling analogy summarizing the broad contention of the oil and gas industry, first conceived by one Canadian executive, but now bandied about at conferences and meetings regarding Canadian energy:

\begin{abstract}
Imagine you were a young adult targeting a career in say, engineering or a technical trade, and you were looking at various university or college programs. You find out that you need to make an investment of a certain amount of time (say four years), hard work (40-60 hours per week), and a welldefined tuition cost (\$30,000 over those four years). Then, if you had the necessary talent and met the predefined course requirements, even if rigorous, you would have your degree after four years and the investment would have paid off in knowledge, edification, and career opportunities.
\end{abstract}

\begin{abstract}
Now, imagine considering a post-secondary education program where there is no indication as to how many years of study you'll need and what courses you will have to take, let alone what the requirements will be. The program tuition could vary between $\$ 20,000$ and $\$ 1$ million and in the end, you may not get your degree, even if you meet all the requirements with flying colours; you would have nothing to show for your efforts.
\end{abstract}

The latter example describes how domestic and foreign investors alike fear that Bill C-69 will inevitably lead to a byzantine, even Kafkaesque, approval process for new LNG projects. Conversely, Justin Trudeau's Liberal government and proponents of Bill C-69 contend that the bill is designed to be more streamlined and efficient because it is more comprehensive, and that consultations and public hearings are restricted to set timelines. Fundamentally the approach the federal project assessment has changed - the test of time is required to see if Bill C-69 really lives up to its promises or whether it is indeed the "no pipeline bill" that the industry claims it is. It is important to note however, that transmission pipelines from the producing regions to terminals on the coast, are not subject to NEB (now Canadian Energy Regulator) processes if they begin and end within the same process (this was the case for LNG Canada's Coastal Gas Link).

Overall, this paper argues that this regulatory uncertainty is the principal cause of current investor dissuasion from Canadian LNG. Comparatively, LNG proponents in the USGC have only to get past the FERC approval process, which tends to be substantially quicker and more predictable. ${ }^{89}$

\title{
Government: Ambivalence and naivete continue to impair Canadian competitiveness
}

Since its Confederation in 1867, Canada has not had simultaneously a coherent and successful energy strategy, despite being endowed with such abundant natural resources. ${ }^{90}$ The country has not produced a true supermajor oil and gas company as the UK, France, and the US have. Its most detailed initiative, Pierre Trudeau's National Energy Program enacted in 1980, infamously turned out to be an abject fiasco, substantially reducing Canadian prominence as a global producer. ${ }^{90}$ Coherence and consensus is so difficult because regional factions are partial to their proximate energy sources (defined primarily by geology and hydroelectric capacity) and have contrasting views on Canada-US relations, environmental progressivism, Canada's global role as an energy producer, Indigenous land rights, and interprovincial pipelines, not to mention discrepant beliefs regarding the state's role in economic activity (admittedly ineradicable from any political discourse).

This translates to how an energy investor sees the Canadian government: a country with vacillating, inconsistent and ineffective energy policies, where an inordinate amount of power is conceded to special interest groups rather than the rule-of-law, even though their agendas may be detrimental to the broader population. Canada has promoted and normalised a rent-seeker mentality that acts as an informal royalty payment, but without any transparent governance - this is a terrible form of political uncertainty.

Canada's federal government has done little to address the natural gas and natural gas liquids price routs in Western Canada while global energy investors redirect their capital towards the USGC, where

\footnotetext{
${ }^{89}$ At least in the USGC. Pembina's Jordan Cove LNG project has been challenged to obtain FERC approval for its liquefaction and export facility in Oregon, where opposition to fossil fuel development can be formidable.

${ }_{90}$ Robert Skinner, A National Energy Strategy: The Holy Grail Of Canadian Public Policy, Energy In Canada @150 And Beyond (Energy Council of Canada, 2017).
} 
hundreds of billions of dollars are being invested in infrastructure, petrochemical manufacturing, and LNG export facilities. ${ }^{91}$

Provincial governments have also been fickle in trying to attract investment. The BC Liberal government introduced an LNG tax in 2014 aimed at appropriating more rent from the LNG value chain to provincial coffers, unwisely before any FID had been made. Although the superseding BC NDP government eventually removed the tax to incite LNG Canada's FID, the disapproval it had previously expressed of Petronas' Pacific Northwest LNG was likely part of what scuppered that $\$ 27$ billion project. ${ }^{92}$ To appease the Green Party members of its elected coalition, the BC NDP offers only tepid support to LNG development.

In the same vein, Alberta's provincial government has attempted to lure petrochemical investment, which bolsters Canadian LNG competitiveness and the WCSB in general, away from the USGC to the province's petrochemical cluster near Edmonton, touting its much lower feedstock prices. (Increased petrochemical manufacturing would boost NGL prices and lower Canadian gas breakeven prices even further.) The government's Petrochemical Diversification Program (PDP) amounted to a complex competition among proponent projects for "royalty credits" whereby the government tries to identify which projects are most viable and will yield the most benefits to Albertans. Though the sums offered sound material - $\$ 375$ million allocated so far, with another $\$ 825$ million ostensibly still available to split among chosen winners - these grants are only worth maybe $30-40 \%$ of that number in net present value, given that they are not received until the first few years of operation and appear to be taxable. For the various investors and executives deciding on a \$7-8 billion world-scale cracker, these incentives are exiguous - likely to move the project internal rate of return needle by only perhaps $0.1-0.2 \%$ and do little to offset a capital cost premium in Canada of 20-30\% versus the USGC (slightly less for LNG on the West Coast). These relatively small incentives from the Alberta government seem especially shortsighted given that such a cracker is expected to deliver somewhere on the order of $\$ 100$ billion of economic output over 40 years. Such programs where the government "picks winners and losers," and determines even the size of incentive granted to the winners, creates worrisome uncertainty for investors and comes off as whimsical. Most proponents are unsuccessful and may read into the rejection that they do not have government support. This is especially bewildering for foreign entrants unaware of the cultural and governmental milieu. A simple guaranteed tax break or incentive commensurate to the volumes processed, applied to any project that comes online (COD), would spur much greater investment. ${ }^{93}$

Finally, governments at the provincial and federal levels have done little to dispel aspersions cast at the Canadian energy industry, which in many circles has become the "whipping boy" of global environmental activism. (For example, many detractors of fossil fuels development, primarily based in OECD countries, lambast Canada's oil sands as an environmental pariah despite notable recent reductions in emissions.) It is certainly easier for activists to thwart Canadian energy projects - given the country's historically progressive environmental and socioeconomic values - than protest further development in the USGC or new coal plants in India and China, even if they are more deleterious to the environment. To date, only the Alberta provincial government has made earnest efforts to publicly respond to and rebuke misrepresentations that ultimately taint public and investor sentiment regarding the entire WCSB.

\section{Becoming globally competitive would require a concerted effort}

\section{Does Canada want to be a major LNG player?}

For Canada to become a primary global LNG supplier, rather than a peripheral one, it would need to respond to the following questions:

\footnotetext{
${ }_{91}$ The Accelerated Investment Incentive program in 2018 allowed for capital expenses to be more quickly accelerated, though this has little impact on the project rate of return for a petrochemical or LNG terminal.

${ }^{92}$ Claudia Cattaneo, "'A Tragedy For Canada': Petronas Cancels \$36B LNG Project As B.C. Jacks Up Demands", Financial Post, 2017.

${ }^{93}$ Compare Alberta's PDP program to municipal tax incentives and significantly lower corporate taxes in Texas.
} 
1) Is Canada motivated to play a material role in decreasing GHG emissions and improving air quality (to reduce premature deaths) outside its borders?

Research from the IEA and others shows that LNG supplied from Western Canada to Asia is estimated to yield substantial net reductions in global emissions, greater than those which Canada is likely to enable on its own. CAPP claims that if Canada received $50 \%$ of the GHG emissions credit as an offset for Asian coal-to-gas switching with its LNG, Canada could meet its 2030 Paris Agreement commitments with roughly three more world scale plants. (Current projections show Canada falling more than $150 \mathrm{mtpa}$ short.) LNG Canada touts its own GHG reduction impact projections (including expansion) in Figure 11. To be sure, this all rests primarily on the assumption that in Asia, imported LNG will replace current or future coal capacity and/or that gas will help backstop the development of renewable power's integration into the grid at material levels. Also, Article 6 of the Paris Agreement that deals with offset credit has not yet been ratified. If importing countries like China, India, and Japan do not agree to share their emissions reductions with the LNG exporters (one might question why they would), Canadians will have to accept an increase in their own emissions for the "greater good" of reducing global emissions. While political parties and the Canadian public espouse global reductions, their main motivation and financial support seems to only favour national reductions (even if the impact is much less). It might help if there was some assurance that LNG was indeed replacing the burning of coal, though this becomes tougher in an LNG world that is moving towards a more commodified, spot market.

Figure 11: Net GHG Emissions Impact of LNG Canada alone (including expansion) vs. Coal LNG used to displace coal in China would reduce $\mathrm{CO}_{2}$ emissions by 60 to 90 million tonnes/year. This is equivalent to...
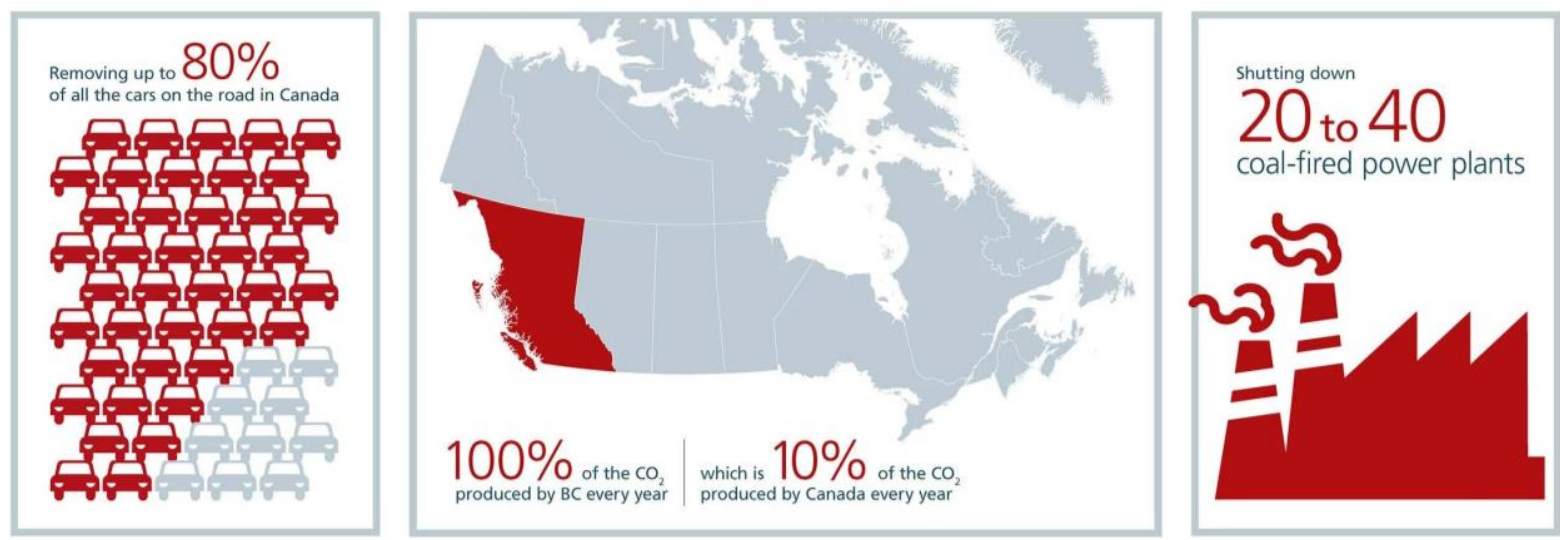

Source: LNG Canada Website (2019)

Beyond GHG emissions, the IEA estimates as of 2015 that 5.5 million annual premature deaths are attributed to poor air quality (approximately two-thirds of which are in Asia), and coal-to-gas switching can significantly reduce this number. ${ }^{72}$ Canada could then claim these benefits are aligned with the federal government's global sustainable development objectives.

Domestic Canadian LNG detractors for environmental reasons tend to be ideologically opposed to any further fossil fuel development and/or to be parochial and unfounded in their thinking that domestic increases in Canadian emissions due to LNG liquefaction (even further minimized with hydroelectricity) will exacerbate global climate change more than the expanding coal usage in Asia.

2) Do Canadians feel that the economic benefits generated by LNG development justify a coordinated and determined effort to address Canadian competitiveness?

From the author's experience with economic impact studies for world-scale LNG and petrochemical plants in Western Canada (with capital investment ranging between $\$ 5$ billion and $\$ 40$ billion), the overall economic output using an input-output model over a 40 -year life, 
discounted at $4 \%$, tends to fall within a multiple of $8-15$ times the initial capital investment. ${ }^{94}$ For LNG Canada for example, with expansion, this overall economic output over 40 years, is estimated by this paper to be between $\$ 320$ and $\$ 560$ billion dollars in present value. Research for this paper does not have direct access to the required inputs or the scope to perform a detailed economic impact analysis, though in its successful application to the Canadian Environmental Assessment Agency, LNG Canada did estimate that over 38,000 full-time equivalent direct, indirect, and induced jobs would be created in Canada from the operation of Phase 1 and the expansion. ${ }^{95}$

Each similar world-scale project could therefore produce a marked boost to Canada's GDP, which was measured at $\$ 1.7$ trillion in 2018 ( $\$ 190$ billion in BC). A 20 mtpa world-scale plant might be expected to generate $\$ 15$ billion in annual economic output and \$9 billion in GDP (on its own corresponding to $0.5 \%$ of Canadian GDP and $4.7 \%$ of BC GDP) ${ }^{96}$ Such impact would enables economic opportunities for Indigenous communities and the funding of Canada's education, healthcare, national defence, and poverty reduction programs. Without LNG growth, federal and provincial governments will be considerably more challenged to provide these services. Also, for developing markets, low-cost Canadian LNG aligns with the federal government's sustainable development goals by improving the standard of living of their low-income populations. ${ }^{97}$

Despite this, many Canadians, including 30\% in BC where the investment is centred, do not see a positive economic impact from LNG Canada or future projects. ${ }^{98}$ Many more acknowledge an impact, but do not consider it, or are unable to grasp its relative importance, when voting. LNG development as a political topic is subsumed within the rubric of "energy", which is dominated by debates on controversial oil export pipelines.

3) What is required for Canada to increase competitiveness?

Domestic gas producers need to gain genuine access to the LNG market - they are all playing on the fringes. Meanwhile the global buyers and traders (from Shell, XOM, Mitsubishi, KOGAS, etc.) are all strengthening their value chain components and will continue to block out those that are outside of the club.

In response to the collapse of WCSB natural gas prices and US gas market domination over the past few years, Canadian energy executives and industry groups have started various alliances, panels, initiatives, conferences and lobby groups to find solutions. (Some executives quip that all the combined acronyms for these consortia amount to a flummoxing "alphabet soup".)

Certainly, intra-industry collaboration is needed - these efforts are worthwhile. But what is needed from government, in collaboration with the energy industry, for Canada to compete for LNG growth? The following list includes both government and industry imperatives: 99

\section{i. Identify and deliver capital costs savings: Industry}

Canadian LNG projects need to find more ways to lower capital liquefaction cost per tonne through working collaboratively with EPCs, leveraging increased modularization, and controlling labour costs. Western Canada must also demonstrate it can deliver such megaprojects with few delays and overruns: potential investors will be keeping a close eye on whether LNG Canada can meet its project targets in the next few years.

\section{ii. Articulating the Canadian LNG story to a wider audience: Government \& Industry}

The environmental, economic, Indigenous, and geopolitical issues surrounding Canadian LNG development are complex, and the vast majority of Canadians (not to mention many federal

\footnotetext{
${ }^{94}$ As these projects are confidential, specific references cannot be made. However, PwC released a 2011 report on mining in British Columbia, which can give the reader a directional understanding of the input-output economic model and approximate multipliers (1.73, for BC mines). The reader could also calculate the additional revenue generated by LNG for BC and Canada over the life-cycle of the project and use a similar multiple to come up with values within the aforementioned range.

952019 https://www.ceaa-acee.gc.ca/050/documents/p80038/101852E.pdf

${ }^{96}$ Calculations by the author are approximate and hypothetical, using a simplified input-output method to indicate order of magnitude economic impacts.

${ }_{97}$ Canada's federal government follows the UN Sustainable Development Goals (SDG). Canadian LNG growth contributes to SDG Goal \#1: No Poverty - End Poverty in all its forms everywhere and SDG Goal \#7: Affordable and Clean Energy.

98 2019. https://www.Ingcanada.ca/news/four-in-five-canadians-support-resource-development-projects/

${ }^{99}$ Government insights shown here are informed partially by work done by GS3 Strategies, an Alberta-based consultancy specializing in energy policy and government relations in Canada.
} 
and provincial members of parliament) are unfamiliar with the basic concepts, let alone the details. Canadian governments should actively promote fact-based messaging and dialogue, as well as respond factually and directly to emotionally-charged calumnies and misinformation from ideological groups masquerading as scientific, economic, or sociological experts, regardless of which side of the argument they arise from, so that informed decisions can be made through legislative and democratic processes. Governments should work to ensure Canadians and foreign investors are aware of Canadian LNG's ESG advantages and disadvantages.

For example, if Canada believes it is a leader in methane release reduction and LNG emission reduction across the value chain, government and industry would benefit from having an objective third party certify that performance with respect to other producing regions, rather than relying on industry claims, which detractors are unlikely to trust.

The challenge for Canada is that its ESG strengths are perceived very differently by stakeholders along the value chain; buyers have not yet placed significant value on a "green" LNG value-chain, especially in Asia. ESG costs need to be considered in terms of uniqueness and potential value add resulting from, for instance, avoidance of future regulatory or stakeholder risk. For example, LNG Canada partners KOGAS and PetroChina may have very different views compared to Shell with their European stakeholder base on avoidance costs and/or stakeholder recognition of methane reduction.

iii. A clear and strong statement of LNG strategy and support from both federal and provincial governments: Government

This is effectively the Prime Minster of Canada, the Premier of British Columbia, the Premier of Alberta, and where possible, leaders of other Canadian provinces, standing on a pressconference stage together to proclaim their joint and avowed commitment to Canadian LNG competitiveness and detail a plan of attack.

iv. Certainty in the Canadian LNG regulatory process: Government

Regardless how Bill C-69 proceeds, in politics and practice, the Canadian regulatory process needs to provide globally competitive clarity and timelines to LNG proponents so that investors are not deterred from even embryonic project development in Canada.

v. Canadian climate-change policy that enables LNG export: Government

Federal and provincial climate change policy needs to target the global reduction of GHG emissions, regardless of Article 6 of the Paris Agreement (though Canada would benefit from its ratification). It needs to not penalize comparatively insignificant domestic emissions at the expense of not shipping LNG to global markets where it could replace coal combustion and/or backstops renewable sources. Operators should be incentivized to reduce GHG emissions across the LNG value chain, ensuring Canadian LNG is the "greenest" in the world. However, incentives should not adversely impact Canadian LNG competitiveness, which would give advantage to less environmentally friendly producing regions.

vi. Clarity around Indigenous rights with regard to LNG development: Government

First Nations can be highly atomized. Even within a single First Nation disputes can exist between elected chiefs, who hold legal power, and hereditary chiefs, who do not have legal power but can wield significant influence. Early consultation from LNG proponents including a governance structure for negotiations and shared benefits is needed. Government needs to enforce a fair and transparent system that does not surrender to one First Nation's demands at the expense of all other First Nations and the broader Canadian public.

vii. Infrastructure connections for gas (corridor and hub concept): Government \& Industry

Producers, midstream operators, LNG proponents and governments could establish a common pipeline corridor that can move natural gas to the West Coast en masse where it would reach a hub that branches out to various LNG projects (similar to the USGC). North America looks to be demand-constrained for natural gas for decades to come - Canada needs an exit valve apart from its southern neighbour. 
viii. Incentives and financing support that reduces development risk and enables producers to stay afloat: Government \& Industry

Canadian governments could incentivize proponents through 1) grants and loan guarantees for proponents to reduce development cost risk before FID 2) credit back-stops for producers to ensure solvency before COD of LNG plants 3 ) corporate tax incentives (such as increased depreciation) to be in line with the USGC and other competitive jurisdictions. Incentives of $\$ 0.5$ 2 billion to unlock $\$ 300-600$ billion of economic benefit for Canada (per project) that otherwise would not transpire, would need to be considered. Allowing the Canada Infrastructure Bank to invest directly in LNG projects, rather than just adjacent infrastructure, could also help.

\section{Current outlook}

\section{Project Update}

The 2015 OIES paper discussed seven Western Canadian LNG projects (five of which were world scale) and four Eastern Canadian LNG projects. ${ }^{100}$ (Before the oil price rout in 2014, there were more than 20 active projects.) Since then, projects have either been cancelled (multiple), shelved (Steelhead's Kwispaa LNG, ExxonMobil's WCC LNG), cancelled but integrated into LNG Canada (Petronas-led Pacific Northwest LNG, BG's Prince Rupert LNG), or active and awaiting FID (shown below):

- Woodfibre LNG (West, $2.1 \mathrm{mtpa}$ ): Smaller, very low-emission project that is close to FID; this paper included its sanctioning in the "Status-Quo Case"

- Chevron/Woodside Kitimat LNG (West, 20 mtpa): Aiming for 2029 COD, with FID in maybe 2022-23; recently increased export license; challenged with producing assets in the remote and more expensive dry gas Horn River basin (rather than the Montney)

- Cedar LNG (West, 3-4 mtpa): Owned by Haisla First Nation; beginning environmental review

- Goldboro LNG (East, $10 \mathrm{mtpa}$ ): Secured 5 mtpa commitment from Uniper in Germany; likelihood of FID is uncertain

- Energie Saguenay LNG (East, $10 \mathrm{mtpa}$ ): Strong headwind of ardent anti fossil fuel activism in Quebec makes this project unlikely to go forward

- Bear Head LNG (East, 4 mtpa)

In addition to the above, there are nascent projects like Rockies LNG (established from a coalition of proactive producers looking for an exit-valve for future production), and though these are still years from FID, COD dates in the second half of the 2020 s are certainly plausible. These emerging projects can even benefit from the skeletons of shuttered projects, lowering their development costs and shortening timelines.

It is revealing to compare the above list to the equivalent list for US or Russian export projects, which have many more projects, much larger scale per project, and are generally more propitious in outlook.

\section{Status-Quo vs. High-Growth Scenarios}

The federal election of October $21^{\text {st }}, 2019$ saw Justin Trudeau's Liberal party lose their majority, though maintain the premiership through a minority government (despite losing the popular vote to the Conservatives). WCSB investors fear this outcome does not bode well for Canadian LNG as regulatory uncertainty could potentially be exacerbated if the Liberals are forced to kowtow to the NDP, Bloc Quebecois, or Green parties, all of whom are against LNG development and for increased politicization of the regulatory process (Bill C-69). The counterargument is that the Liberal government will be intensely focused on making sure that the new Bill C-69 legislation delivers approvals to avoid further Western alienation (the Liberal Government did not win any seats in Saskatchewan and Alberta).

${ }^{100}$ Ieda Gomes, Natural Gas In Canada: What Are The Options Going Forward? (Oxford: Oxford Institute for Energy Studies, 2019). 
This paper projects that assuming, at best, a status-quo state of regulatory headwinds (where uncertainty endures), Canada is unlikely to build another major greenfield LNG plant (beyond LNG Canada's expansion phase) by 2030 , for a total of roughly $30 \mathrm{mtpa}$ or 4 bcfd (the "Status-Quo Case"). ${ }^{101}$

A more concerted effort by federal and provincial governments, to make Canadian LNG more competitive, one that delivers increased definition and predictability around the regulatory approval process, if paired with improved capital costs, can be expected to incite two new world-scale greenfield plants for an estimated total production of roughly $75 \mathrm{mtpa}$ or 10 bcfd by 2030 (this paper's "HighGrowth Case"). Some Canadian energy executives feel there is easily potentially for $100 \mathrm{mtpa}$ or more.

To be sure, analysts and economists (including the OIES, earlier this year) ${ }^{102}$ do not predict that Canadian LNG will grow with anywhere near the meteoric trajectory expected for the USGC (with already over $100 \mathrm{mtpa}$ of sanctioned projects). That said, the global LNG competitive landscape and investor sentiment tends to change rather quickly. For example, a reversal of political control in Canada and the US (democratic control in the US and conservative control in Canada), especially if combined with a slowdown of investment into US LTO and shale gas production, could change the LNG outlook for both countries substantially.

\footnotetext{
101 One or two smaller LNG plants like Woodfibre LNG (2 mtpa) are likely to be sanctioned.

102 Claudio Steuer, Outlook For Competitive LNG Supply (Oxford Institute for Energy Studies, 2019).
} 


\section{Appendix: Haisla Nation Letter}

An open letter to opponents and critics of LNG development, from Chief Councillor Crystal Smith of the Haisla First Nation (January $\left.8^{\text {th }}, 2019\right): 103$

When we see what we are achieving as a Nation through our support of LNG Canada and the Coastal GasLink pipeline, we know our support has been well placed.

Let's put aside terms like "benefit agreements" for a moment, because that's merely the medium for how we realize our success.

For now, let's actually talk about the people.

Just last week we hosted the first in a series of Haisla Christmas celebrations. In Vancouver, our Community Cultural Coordinator revealed a Haisla language words and phrases sheet, and she was met with loud applause for the effort she and her entire program have put in to revitalizing the Haisla culture.

If it weren't for the respectful and impactful negotiations and discussions we've had to date with LNG Canada and Coastal GasLink, she would not be there to offer that one extra tool, not to mention all the other work of the program, to maintain and enhance our community's connection to our language.

We have dedicated office space for our Education \& Employment department, through which our Job Coaches, job placement coordinators, and more work towards giving our members access to jobs and the training they need to reach their goals.

If it weren't for the open communication and the continued offer of respect from LNG Canada and Coastal GasLink as they engaged with Haisla, we would not have those services in place.

This land has been our home for thousands of years. The relationship between our Nation and industry has never been this healthy and open. Industry has come and gone from our Territory and not until now have we had this much influence in seeing it happen responsibly, and sustainably.

What guides our decision-making is whether a project will make the right choices to maintain and enhance the environment, and whether the proponents will properly and effectively include Haisla people to enhance our quality of life.

LNG Canada and Coastal GasLink have met our standards.

We urge you to think strongly about how your opposition to LNG developments is causing harm to our people and our wellbeing. Opposition does nothing towards empowering our Nation, but rather dismisses our Rights and Title and works towards separating our people from real benefits.

103 "An Open Letter On Why Haisla Nation Stands Behind LNG - Haisla Nation", Haisla Nation, 2019, https://haisla.ca/an-openletter-on-why-haisla-nation-stands-behind-Ing/ 